OPEN ACCESS

Edited by:

Mónica Pradillo,

Complutense University of Madrid,

Spain

Reviewed by:

Jason Sims,

Max F. Perutz Laboratories GmbH,

Austria

Charles Underwood,

Max Planck Institute for Plant

Breeding Research, Germany

Heïdi Serra,

Centre National de la Recherche

Scientifique (CNRS), France

*Correspondence:

Arnaud Ronceret

arnaud.ronceret@ibt.unam.mx

Specialty section:

This article was submitted to

Plant Cell Biology,

a section of the journal

Frontiers in Plant Science

Received: 30 May 2021

Accepted: 13 August 2021

Published: 07 September 2021

Citation:

Gutiérrez Pinzón Y, González Kise JK, Rueda P and Ronceret $A$ (2021) The Formation of Bivalents and the Control of Plant Meiotic

Recombination.

Front. Plant Sci. 12:717423. doi: 10.3389/fpls.2021.717423

\section{The Formation of Bivalents and the Control of Plant Meiotic Recombination}

\author{
Yared Gutiérrez Pinzón, José Kenyi González Kise, Patricia Rueda and \\ Arnaud Ronceret*
}

Laboratory of Cytogenomics of Meiosis, Instituto de Biotecnología, Departamento de Biología Molecular de Plantas, National Autonomous University of Mexico (UNAM), Cuernavaca, Mexico

During the first meiotic division, the segregation of homologous chromosomes depends on the physical association of the recombined homologous DNA molecules. The physical tension due to the sites of crossing-overs (COs) is essential for the meiotic spindle to segregate the connected homologous chromosomes to the opposite poles of the cell. This equilibrated partition of homologous chromosomes allows the first meiotic reductional division. Thus, the segregation of homologous chromosomes is dependent on their recombination. In this review, we will detail the recent advances in the knowledge of the mechanisms of recombination and bivalent formation in plants. In plants, the absence of meiotic checkpoints allows observation of subsequent meiotic events in absence of meiotic recombination or defective meiotic chromosomal axis formation such as univalent formation instead of bivalents. Recent discoveries, mainly made in Arabidopsis, rice, and maize, have highlighted the link between the machinery of double-strand break (DSB) formation and elements of the chromosomal axis. We will also discuss the implications of what we know about the mechanisms regulating the number and spacing of $\mathrm{CO}$ (obligate $\mathrm{CO}, \mathrm{CO}$ homeostasis, and interference) in model and crop plants. Keywords: Meiosis, recombination, synapsis, obligate crossing-over, interference, co homeostasis,
heterochiasmy

\section{INTRODUCTION}

Meiosis is one of the most dynamic processes for a plant genome (Ronceret and Pawlowski, 2010; Prusicki et al., 2019). To achieve a reductional division, the meiotic cell goes through one round of DNA replication followed by two cell divisions (Mercier et al., 2015). The meiotic divisions have evolved from the machinery toolkit used by the regular mitotic division with additional regulatory functions allowing the reductional division (Wilkins and Holliday, 2009). Several differences between meiosis and mitosis are discernible already at prophase I with the introduction of meiotic-specific processes such as meiotic recombination, pairing, and synapsis of homologs. During the whole meiotic prophase I, the nuclear chromosome content is duplicated and each homolog is constituted by two sister chromatids. Bivalents are defined as connected homologous chromosomes, forming a unit of four DNA molecules, essential for the equilibrated segregation of the chromosome pool. The formation of bivalents occurs during the prophase I of meiosis and involves the coordination between homologous recombination, pairing, and synapsis (Mercier et al., 2015). During meiotic metaphase I, a specific bipolar conformation of the meiotic spindle attachment to centromeres allows the segregation of these recombined bivalents. 
In plants, male and female meiosis occur in different organs. Though most meiotic mechanisms are shared between sexes, some differences have long been observed between male and female meiotic recombination rates. After the two successive meiotic divisions, haploid spores, which contain only one set of each chromosome, are formed. These separated male or female spores undergo the gametophytic phase giving rise to distinct male and female gametes. Fertilization between gametes restores the diploid state crucial for the sexual life cycle and the genome maintenance of the species.

Understanding the formation of how new meiotic DNA molecules are formed is of special value for breeding since it is a fundamental basis for genetics, evolution, and genomic crop improvement (Melamed-Bessudo et al., 2016; Lambing et al., 2017; Blary and Jenczewski, 2019; Bolaños-Villegas and ArgüelloMiranda, 2019; Taagen et al., 2020; Kuo et al., 2021).

This review will focus on the recent advances in the understanding of the genetic control of meiotic recombination and bivalent formation in diploid plant species, mainly Arabidopsis, rice, and maize. For the more complex bivalent and multivalent formation in polyploid plants [Refer the reviews of Cifuentes et al. (2010), Mason and Wendel (2020), and Svačina et al. (2020)]. Several important discoveries have been made in these last few years concerning the mechanisms of crossing-over (CO) interference (impeding the formation of adjacent COs), non-crossing-over (NCO) pathways, obligate $\mathrm{CO}$ (to maintain at least one $\mathrm{CO}$ by bivalent), $\mathrm{CO}$ homeostasis [the buffering of $\mathrm{CO}$ numbers despite the reduction in double-strand breaks (DSBs) number], and heterochiasmy (difference in male and female $\mathrm{CO}$ frequencies). For an overview of the plant meiotic genes and mechanisms discovered before 2018, see the excellent reviews of Luo et al. (2014), Mercier et al. (2015), and Wang and Copenhaver (2018). An overview of the proteins regulating bivalent formation grouped by functional modules is listed in Figure 1.

\section{REGULATION OF THE MEIOTIC CELL FATE AND MEIOTIC TRANSCRIPTOME}

In plants, the germline fate acquisition where meiosis will occur involves the specific transcription factor SPOROCYTELESS also known as NOZZLE in Arabidopsis (Yang et al., 1999; Wei et al., 2015) and rice (Ren et al., 2018). In rice, the ARGONAUTE protein MEL1 plays an essential role in male and female meiotic cell fate (Nonomura et al., 2007; Komiya et al., 2014; Liu and Nonomura, 2016). The rice MEL2 is an RNA recognition motif protein binding the $3^{\prime}$-UTRs and involved in the translational regulation of key meiotic genes (Nonomura et al., 2011; Miyazaki et al., 2015). In Arabidopsis, no MEL orthologs have been described but AGO9 and AGO4 are involved in female gamete specification (Olmedo-Monfil et al., 2010), while small interfering RNA inhibits retrotranspositions in the male germline (Long et al., 2021). Argonautes are the key players in distinct small RNAs (sRNAs) pathways involved in transcriptome regulation (Oliver et al., 2014). Transcriptomic analysis of different steps of germline cells and meiocytes has revealed dramatic transcriptomic changes during prophase I in various plant species. In maize, single-cell
RNA sequencing reveals a profound two steps reorganization of the transcriptome at the leptotene stage when meiotic recombination initiate (Nelms and Walbot, 2019). The sRNAs (micro-RNA and phased secondary small interfering RNA) are particular dynamics during prophase in rice, maize, sunflower, soybean, and cucumber (Dukowic-Schulze et al., 2016; FlórezZapata et al., 2016; Huang et al., 2020; Zhang et al., 2021) and, at least in Arabidopsis male meiocytes, play a critical role in meiotic recombination potentially via the AGO4 pathway (Oliver et al., 2016, 2017; Pradillo and Santos, 2018).

Though sex-specific transcriptomes have been obtained in various plant species (Dukowic-Schulze et al., 2020; Liu et al., 2020; Barakate et al., 2021), a systematic comparison between male and female meiotic transcriptomes has not yet been performed.

In maize, hypoxia arising naturally within growing anther tissue was reported to act as a positional cue to set male germ cell fate (Kelliher and Walbot, 2012). The cytology of plant female meiosis has been historically more challenging but is now prone to analysis due to new techniques of the whole immunolocalization of plant ovules (Escobar-Guzman et al., 2015; Gordillo et al., 2020). In Arabidopsis, the specification of only one germ cell line per ovule has been analyzed and involved complex positional clues and identify RBR1 as a central hub for female meiocyte differentiation (Zhao et al., 2017). RBR1 is also required for the recombinase RAD51 localization to DNA lesions (Biedermann et al., 2017). SWITCH1/AMEIOTIC is an essential gene allowing the entry in male and female meiosis. SWI1 was recently identified as a functional Sororin-like antagonist (Yang et al., 2019) of the WINGS APART-LIKE (WAPL) that removes cohesin from chromosome via the prophase pathway before the action of separase at anaphase onset (De et al., 2014). Accordingly, SWI1/AM1 is a nuclear protein installed on the whole chromatin from premeiotic replication and is only maintained in centromere regions during pachytene in maize (Pawlowski et al., 2009). However, this remaining centromeric localization was not observed in rice (Che et al., 2011) suggesting plant-specific variations for this regulation.

\section{FORMATION OF THE MEIOTIC COHESIN COMPLEX}

DNA replication is followed by the appearance of meiotic-specific components of the cohesin complex (formed by SMC1, SMC3, SCC2, SCC3, and REC8) (Cai et al., 2003; Chelysheva et al., 2005; Wang et al., 2020). Cohesin turnover and localization on chromatin are mediated by WAPL (De et al., 2014), PDS5 (Pradillo et al., 2015), and CTF7 (Singh et al., 2013). REC8 is a meiotic-specific kleisin that replaces the mitotic SCC1 subunit in this complex. It was shown in tomato that the four subunits of the meiotic cohesin complex are discontinuously distributed along the chromosome length from leptotene through early diplotene (Qiao et al., 2011). In maize, SMC3 is essential for sister chromatid cohesion and facilitates centromere coupling (Zhang et al., 2020d), a peculiar configuration associating the centromeres before pairing commences along chromosome 


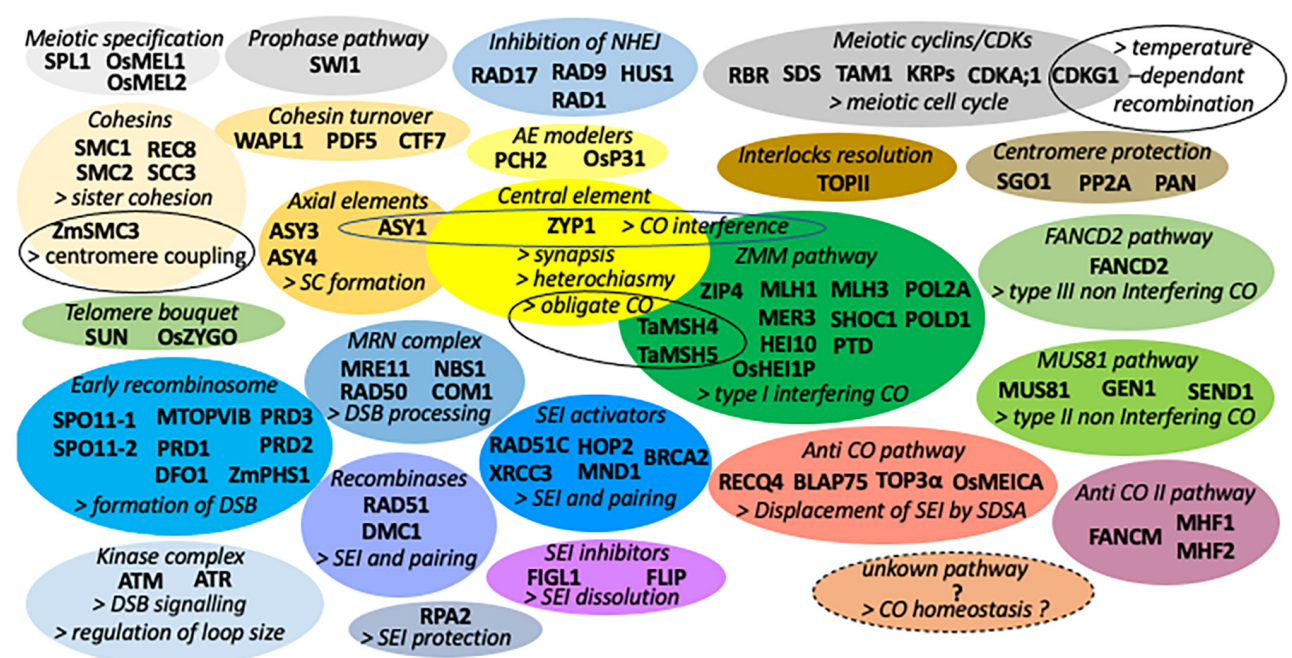

FIGURE 1 | List of proteins regulating bivalent formation grouped by functional modules under a different colored bubble. For simplification, the list only gives the name of Arabidopsis proteins unless the two-letter symbol of the species is specified before the protein name (Os rice, Ta durum wheat, and Zm maize).

arms (Ronceret et al., 2009). The current working models of chromatin organization suppose that the meiotic cohesin complex forms a ring attaching the two replicated sister chromatids and organizes the chromatin by forming the base of chromatin loops (Zickler and Kleckner, 2015; Kim and Choi, 2019; Grey and de Massy, 2021). Chromosome conformation capture $(\mathrm{HiC})$ experiments have not yet been performed on plant meiotic genomes to analyze their chromosomal loop domain organization (Golicz et al., 2020). In Arabidopsis, ChIP-seq experiments have shown that REC8 is associated with repetitive centromeric and pericentromeric regions of high nucleosome occupancy, the opposite of where meiotic DSBs and crossovers are found at the chromosome and fine scales (Lambing et al., 2020b). REC8 containing cohesin complex is largely protected by the Shugoshin (SGO)-PP2A complex around centromeres during meiosis I (Zamariola et al., 2014; Yuan et al., 2018; Zhang et al., 2019) and by PAN during interkinesis (Cromer et al., 2019). These protections allow the coordinated separation of the homologous chromosomes during meiosis I and the release of the sister chromatin only during meiosis II via a separasedependent proteolytic cleavage of the centromeric kleisin subunit REC8 (Cromer et al., 2019).

\section{FORMATION OF THE AXIAL ELEMENT OF THE SYNAPTONEMAL COMPLEX}

The synaptonemal complex (SC) is a proteinaceous ultrastructure formed of two axial elements (AEs) and a central element. Elements of the AEs are installed on chromatin during leptotene before synapsis occurs. In plants, several components of the AEs have been identified: the HORMA domain ASY1/PAIR2 (Armstrong et al., 2002; Nonomura et al., 2004a), the associated coiled-coiled proteins ASY3/DSY2/PAIR3 (Yuan et al., 2009; Ferdous et al., 2012; Lee et al., 2015; Osman et al., 2018) and
ASY4 (Chambon et al., 2018). The cohesin REC8 is supposed to anchor chromatin to the AEs of the SC via PAIR3/ASY3 (Wang et al., 2011) though a direct interaction between REC8 and any AE protein is yet unknown. However, in Arabidopsis, ASY1 and REC8 ChiP-seq strongly correlate suggesting that both proteins associate with similar regions of the genome at global and fine scales (Lambing et al., 2020b). In maize, DSY2 (homolog of ASY3 and PAIR3) forms an alternative pattern with ASY1 on AE and can interact with ZYP1 while ASY1 cannot (Lee et al., 2015). In addition, the $\mathrm{AAA}^{+}$ATPase PACHYTENE CHECKPOINT 2 (PCH2)/CRC1 is essential for the ASY1 depletion before synapsis (Lambing et al., 2015). Its interacting partner P31 ${ }^{\text {comet }}$ participates in ASY1 import in the nucleus and the removal of non-phosphorylated ASY1 from the chromosomal axis (Balboni et al., 2020). In rice, CRC1/PCH2 can directly interact with ZEP1/ZYP1 while P31 cannot (Ji et al., 2016). In addition, the role of some SC proteins in the initiation of meiotic recombination such as DSY2/ASY3 in maize (Lee et al., 2015), CRC1/PCH2 (Miao et al., 2013) and P31 in rice (Ji et al., 2016) pinpoints to the essential role of $\mathrm{AE}$ elements on the initiation of meiotic recombination.

\section{FORMATION OF THE EARLY RECOMBINOSOME}

During meiosis, two homologous DNA molecules can form new recombined ones using the general mechanics of the errorproof DNA damage repair pathways (Mercier et al., 2015; Wang and Copenhaver, 2018; Zelkowski et al., 2019). The initiation of meiotic recombination starts with the introduction of DNA DSBs. The DSBs are formed by the SPO11 complex composed of the catalytical A subunits, SPO11-1 (Grelon et al., 2001; Edlinger and Schlögelhofer, 2011; Da Ines et al., 2020) and SPO11-2 (Stacey et al., 2006; 
Hartung et al., 2007b; Benyahya et al., 2020), associated with two B subunits, called MTOPVIB of the class II topoisomerase type VI (Fu et al., 2016; Vrielynck et al., 2016; Xue et al., 2016). The Arabidopsis spo11-1 mutant has an interesting distinctive 23 and 24 nt sRNA profile than wild type in male meiocytes. These SPO11-1-dependent sRNAs are mapped to bind coding sequences and some CO feature motifs, while some sRNAs can target some meiotic genes such as RAD51 or ASK1 (Huang et al., 2019). Whether or not these sRNAs are produced at or near the site of DSBs and represent a signaling mode for repairing the DSB requires further work.

Though every CO is derived from a DSB event, not all DSBs are repaired as COs, and a vast majority of DSBs result in NCOs (Mercier et al., 2015). In maize, the CML228 inbred line that has naturally less DSBs (evaluated by the RAD51 number) has a correlated decreased CO number compare to B73 and other inbreds, indicating that the level of CO homeostasis is limited (Sidhu et al., 2015). In Arabidopsis, hypomorphic spo111 mutants that reduce the DSB number also diminish the CO number but interestingly also alter the pattern of $\mathrm{CO}$ toward the telomeres (Xue et al., 2018). These data suggest that, at least in these two model plant species, CO homeostasis is not observed or limited.

In maize, using superresolution microscopy, it was observed that only a subset of SPO11-1 foci, the one closely associated with the AEs, correspond to the number of DSBs formed in leptotene ( $\mathrm{Ku}$ et al., 2020). This suggests that the topoisomerase II-like nuclease function of the SPO11-1 complex occurs only when it is associate with the $\mathrm{AE}$ ( $\mathrm{Ku}$ et al., 2020). Whether or not this particular configuration allows the nuclease activity of only one of the two attached sister chromatids is not known. The SPO11-1 "early recombinosome" complex also contains various accessory proteins that might participate in the tethering between the chromatin loop and the axis where DSBs are formed. SPO111 and MTOPVIB can interact with PRD1 (Vrielynck et al., 2016; Tang et al., 2017). In addition, rice and maize MTOPVIB, rice PRD1, and Arabidopsis PRD2/MPS1 are required for the assembly of the meiotic bipolar spindle (Ji et al., 2016; Xue et al., 2019; Jing et al., 2020; Shi et al., 2021). It was long recognized in maize that the meiotic spindle can associate around chromatin independently of the formation of the bivalent (Chan and Cande, 1998; Nannas et al., 2016) suggesting that the multipolar spindle observed in the meiotic recombination mutants might be a consequence of the formation of univalents instead of bivalents. The rice PRD1 initially forms numerous foci during leptotene, progressively restricted to few foci colocalizing with centromeric CENH3 and other kinetochore proteins (MIS12, NDC80, and CENP-C) at pachytene (Shi et al., 2021). PRD1 can directly interact with REC8 and SGO1 (Shi et al., 2021) suggesting a mechanism for early coordination between DSB formation and meiotic spindle organization. Other SPO11-associated factors such as DFO1, PRD1, PRD2, and PRD3/PAIR1 have also been identified as essential for DSB formation (Nonomura et al., 2004b; De Muyt et al., 2007, 2009; Zhang et al., 2012) but their relationship, specific function, and potential interaction with the cohesin and AE proteins still need to be explored (Mercier et al., 2015; Kim and Choi, 2019). PHS1, discovered in maize (Pawlowski et al., 2004), is poorly conserved with the rec114 yeast DSB factor but has a divergent function in plants. It is involved in the nuclear localization of the RAD50 protein into the nucleus in maize and Arabidopsis (Ronceret et al., 2009). SKI8 is also not conserved between yeast and Arabidopsis (Jolivet et al., 2006). Interestingly, the PRD2/MPS1 can form different splicing isoforms depending on the methylation status of its intron 9, dependent on the RNA-directed DNA methylation pathway (Walker et al., 2018).

\section{GENOMIC MAPPING OF DSBS AND RECOMBINATION MOTIFS}

Several studies using ChIP or SPO11 oligonucleotide sequencing have now revealed the genomic pattern of DSBs in maize and Arabidopsis. As previously well-known, genomes contain hotspots of COs, that are now correlated with genomic hotspots regions more prone to form DSBs (He et al., 2017; Choi et al., 2018; Tock and Henderson, 2018). In these two diploid species, DSBs are associated with specific active chromosome features such as transcriptional start sites that are depleted of nucleosomes. In Arabidopsis, several motifs associated with recombination have been defined. The A-rich motif is preferentially associated with promoters, while the CCN repeat and the CTT repeat motifs are preferentially associated with genes (Shilo et al., 2015). The motifs correlating with COs are not necessarily identical to motifs correlating with sites of DSB. This suggests that several genomic contexts required for the different steps of recombination progressively shape the choice of chromosomal exchange sites. The presence of a similar but not identical 20-bp-long GC-rich degenerate DNA sequence motif was correlated with DSB formation in maize and Arabidopsis ( $\mathrm{He}$ et al., 2017; Choi et al., 2018). Interestingly, while DSBs are also formed in regions that will not form $\mathrm{CO}$ such as centromeric regions and repetitive DNA (especially RNA transposons), it was found that only DSBs formed in genic regions will form CO in maize (He et al., 2017). In Arabidopsis, mutants affecting the methylation of H3K9me2 and DNA CG and non-CG in the transposon-rich pericentromeric heterochromatin also increase the formation of DSB near centromeres (Underwood et al., 2018; Fernandes et al., 2019). In maize, the mop1 mutation (homolog of RDR2) that removes $\mathrm{CHH}$ methylation adjacent to hotspots also affects the recombination landscape, increasing it in the chromosome arm but decreasing it in pericentromeric regions (Zhao et al., 2021). These data indicate that though the molecular bases are distinct in species of different genome sizes, and with relative repetitive element contents, a strong effect of epigenetic and chromatin state controls the fate of the early meiotic recombinosome.

\section{SIGNALING AND PROCESSING OF THE DSBS}

The programmed DSBs are identified by the signaling pathway of DNA damages via the ATM and ATR kinases (Kim and Choi, 2019; Zhang et al., 2020a). In budding yeast, ATM/ATR can phosphorylate REC8 and other chromosome 
axis proteins and, therefore, modulate $\mathrm{CO}$ homeostasis (Kim and Choi, 2019). It is not clear, however, if this is also the case in plants. The meiocyte nuclei use prepared recombination machinery to repair the numerous endogenous DSBs using a preferential homologous recombination pathway. The somatically preferred non-homologous end joining (NHEJ) is suppressed by the exonuclease (RAD9-RAD1-HUS1) 9-1-1 complex system (Che et al., 2014; Hu et al., 2016). This 91-1 complex itself is possibly recruited by the DNA damage sensor RAD17 (Hu et al., 2018). This inhibition is essential to avoid inaccurate interactions between non-homologous chromosomes during meiosis (Che et al., 2014). The DSBs are rapidly associated with the phosphorylation of histone $\mathrm{H} 2 \mathrm{AX}$ and processed by endonuclease and exonucleases activities of the MRN complex composed of MRE11, RAD50, NBS1, and COM1 (Bleuyard et al., 2004; Puizina et al., 2004; Uanschou et al., 2007; Waterworth et al., 2007; Lohmiller et al., 2008; Šamanić et al., 2013; Wang Y. et al., 2018) creating 5' overhang sequences. These sequences are recognized by specialized single DNA strand affine replication protein A (RPA) types such as RPAla in Arabidopsis (Osman et al., 2009) or RPA1C and RPA2C in rice (Li et al., 2013). RPAs are generally involved in telomere-length maintenance (Aklilu et al., 2020) suggesting a functionalization of this single DNA strand capping for the processing of meiotic DSBs.

\section{SINGLE-END INVASIONS AND PAIRING}

These single ends can invade homologous sequences (process called single-end invasion or SEI) thanks to the recombinase activities of RAD51 and DMC1 (Couteau et al., 1999; Li et al., 2004). These recombinases have the properties to form a strong homology-based DNA triple helix called a displacement loop (D-loop) (Kurzbauer et al., 2012; Wang et al., 2016; Singh et al., 2017; Colas et al., 2019; Draeger et al., 2020). The RAD51 and DMC1 are part of the same recombinase protein family also containing RAD51C and XRCC3 that derive from the same ancestor but have undergone subfunctionalization (Bleuyard et al., 2004; Da Ines et al., 2013; Pradillo et al., 2014). RAD51C and XRCC3 facilitate the RAD51 chromosome localization (Su et al., 2017; Jing et al., 2019; Zhang et al., 2020c). RAD51 and DMC1 also associate with other proteins modulating their activities such as BRCA2 (Siaud et al., 2004; Dray et al., 2006; Seeliger et al., 2012; Fu et al., 2020), FIGL1 and FLIP (Zhang P. et al., 2017; Fernandes et al., 2018a; Kumar et al., 2019), or MND1, and HOP2 (Vignard et al., 2007; Uanschou et al., 2013; Aklilu et al., 2020). Rice MND1/MSF1 can interact with RPA2b and HOP2 (Lu et al., 2020), while OsHOP2 can directly interact with the SC central element ZEP1/ZYP1 suggesting a second mechanism for the link observed between early recombination and synapsis (Shi et al., 2019) at the SEI step. The excess number of SEI creating several interconnections between homologous chromosomes (also called interhomolog joint molecules) were proposed to be involved in the pairing process (Pawlowski et al., 2003). Pairing allows the recognition between accurate homologs before its stabilization by the polymerization and lateral extension of the SC during zygotene.

\section{ANTICROSSOVER PATHWAYS}

The number of DSB and SEI is far greater than the number of COs and the vast majority of DSBs [around 85\% in Arabidopsis (Higgins et al., 2004) and 97.7\% in durum wheat (Desjardins et al., 2020)] are resolved as NCOs. NCOs are formed when the SEI occurs on the sister chromatid but also when a D-loop formed on the homologous chromosome is resolved in a configuration that only involves the exchange of genetic material in a short sequence called conversion tracts (Mercier et al., 2015; Wang and Copenhaver, 2018). Three parallel antiCO pathways have been discovered using suppressor genetic screens of $z \mathrm{~mm}$ meiotic recombination mutants in Arabidopsis (Séguéla-Arnaud et al., 2015).

The first NCO pathway involves the SGS1/BLM helicases homologs RECQ4A and RECQB (Hartung et al., 2007a; Higgins et al., 2011) and the topoisomerases TOP3 $\alpha$ (Hartung et al., 2008) associated with BLAP75/RMI (Chelysheva et al., 2008), which unwinds D-loops leading to a sixfold CO number increase in Arabidopsis (Séguéla-Arnaud et al., 2015). In rice, the MEICA protein that interacts with TOP3a also has an anticrossover activity (Hu et al., 2017).

The anti-CO pathway that involves the FANCM helicase possibly displaces the invading strand through the synthesisdependent strand annealing (SDSA) process (Crismani et al., 2012). SDSA can form NCOs by annealing the SEI with the other end of the DSB, repairing the DSB using the original DNA molecules. FANCM has two binding cofactors MHF1 and MHF2 that also limit the number of COs formed via the type II non-interfering pathway (Dangel et al., 2014; Girard et al., 2014). Interestingly, the anti-CO effect due to FANCM is more pronounced in inbred than in hybrids backgrounds (Girard et al., 2015). The FANCM pathway also affects COs in a Brassica rapa pure line (Blary et al., 2018). In lettuce, the fancm mutant shows a univalent phenotype not observed in other species ( $\mathrm{Li}$ et al., 2021) indicating possible divergence in the regulation of this pathway or different consequences between species of different genome sizes.

Another cumulative NCO pathway involves the FIDGETIN AAA-ATPase FIGL1 (Girard et al., 2015; Zhang P. et al., 2017) and its partner FLIP (Fernandes et al., 2018a). FIGL1 directly interacts with RAD51 and DMC1 and is proposed to limit SEI and CO number (Fernandes et al., 2018a). Using the mutants of these different pathways or combining them together or with elevated expression of the procrossover factors HEI10 (Serra et al., 2018) are particularly interesting for agronomy since it allows to unleash the number of CO by several folds in various plant species and potentially speed up new breeding strategies (Fernandes et al., 2018b; Mieulet et al., 2018). Interestingly, these $\mathrm{CO}$ increase do not cause problems in chromosome segregation. The relative role of these different pathways in male vs. female plant meiosis requires further analysis. 


\section{SYNAPSIS AND ROLE OF THE SC IN THE REGULATION OF RECOMBINATION}

The central element ZYP1 of the SC starts polymerizing during zygotene to form a protein complex resembling a zipper structure connecting the two meiotic homologous chromosomes from telomere to telomere at pachytene. The two AEs are called lateral elements once they form this tripartite structure (Higgins et al., 2005; West et al., 2019; Darrier et al., 2020; Kurzbauer et al., 2021). Although two redundant ZYP1 proteins sharing 87\% identity are present in Arabidopsis; their relative role is still unknown. The SC can regulate the number and spacing of $\mathrm{CO}$. While barley zyp1 mutants show limited $\mathrm{CO}$ numbers (Barakate et al., 2014), the homolog rice zep1 mutants have the opposite effect (Wang et al., 2010). The SC components have diverged rapidly among eukaryotes but the general SC structure is conserved (West et al., 2019). These results might reflect divergent modes of regulation of the SC on $\mathrm{CO}$ between different species. ZYP1 was also recently reported as required for CO interference and the obligate CO (France et al., 2021). In Arabidopsis zyp1a/b null mutant, heterochiasmy is abolished (Capilla-Pérez et al., 2021). These recent data suggest that the SC coordinates the regulation of obligate $\mathrm{CO}$, interference, and heterochiasmy. Arabidopsis asy1 mutants also abolish CO interference (Lambing et al., 2020a). ASY1 acts as an antagonist of telomere-led recombination in a gene dosage-sensitive manner (Lambing et al., 2020a). The ASY1 immunolocalization signal disappears concomitantly with the loading of the central element ZYP1 (Lee et al., 2015). This suggests that obligate CO, heterochiasmy, and interference mechanisms are not directly mediated by either ASY1 or ZYP1 but rather involve the regulation of the SC length. ASY1 can be phosphorylated by CDKA; 1 counteracting the ASY1 disassembly activity of $\mathrm{PCH} 2$ and P31 (Yang et al., 2020), which suggests a dynamic control of SC length regulation. The phosphorylation of the ASY1 protein increases its binding affinity with the chromatin-anchoring ASY3/DSY2 protein (Yang et al., 2020). ATM is another meiotic protein kinase essential to limit DSB number; it regulates chromatin loop size and affects SC length and width (Kurzbauer et al., 2021). The relative role of ATM and CDKA1;1 in the phosphorylation of SC components or other meiotic proteins is still unknown.

\section{FORMATION OF THE LATE RECOMBINOSOME AND CROSSOVER PATHWAYS}

The DNA repair of the damaged molecules involves the formation of double Holliday junctions ( $\mathrm{dHJs}$ ) that are resolved by resolvases leading to $\mathrm{CO}$ or NCO. Two pathways of $\mathrm{CO}$ formation have been described in plants.

The interfering pathway (CO type I) positions $\mathrm{CO}$ with nonrandom spacing between each $\mathrm{CO}$ event. In general, the $\mathrm{CO}$ type I accounts for the majority (80-95\%) of all COs in plant species (Mercier et al., 2015). It involves the ZMM pathway, namely,
MER3 (Chen et al., 2005; Mercier et al., 2005), ZIP4 (Chelysheva et al., 2007), the DNA mismatch repair mutS/mutL homologs MSH/MLH (MSH4, MSH5, MSH7, MLH1, and MLH3) (Higgins et al., 2004, 2008b; Chelysheva et al., 2010; Colas et al., 2016) and HEI10 (Chelysheva et al., 2012; Ziolkowski et al., 2017). In rice, a new member of the ZMM pathway was discovered through its interaction with HEI10, MSH4, and ZIP4 and named HEI1P1 (Li et al., 2018). SHOC1 and PTD, which were described in Arabidopsis as involved in the type I CO pathway (Macaisne et al., 2008, 2011), are conserved and play similar roles in rice (Ren et al., 2019). Interestingly, it was found that the obligate COs (that ensure the correct chromosome segregation during anaphase I) are maintained by MSH4 and MSH5 in durum wheat (Desjardins et al., 2020). In the allotetraploid Brassica napus, reducing the MSH4 copy number prevents non-homologous CO (Gonzalo et al., 2019). The analysis of hypomorph mutants of two essential B-class DNA polymerases (the delta POLD1 supposed to be involved in DNA lagging strand synthesis and the Epsilon POL2A thought to be involved in DNA leading strand synthesis) has shown that they are also involved in the formation of type I COs (Huang et al., 2015; Wang C. et al., 2018). It was first hypothesized that elongation activity of these polymerases is required for the process of meiotic recombination but the multifunctionality of these POL proteins, containing exonuclease proofreading domains (Ronceret et al., 2005), could complicate the interpretation of the activity required during meiotic recombination. In addition, DNA polymerases are involved in the deposition of the H3K4me3 transcriptionally active epigenetic marks linked to DSB formation and participate in DNA repair (Yin et al., 2009; Iglesias et al., 2015) suggesting other possibilities for the role of DNA POL in the formation of type I COs. However, since most of the pol mutants have embryolethality phenotypes (Ronceret et al., 2005; Wang et al., 2019) this is a difficult topic to study.

The second minor CO pathway (type II or non-interfering) can form closely spaced COs. In plants, it involves the $\mathrm{dHJ}$ resolvases (structure-specific endonuclease) MUS81 (Higgins et al., 2008a), GEN1 (Wang et al., 2017), and SEND1, which is also essential for telomere stability (Geuting et al., 2009; Olivier et al., 2015).

Though it was found to be involved in the mechanism of interference in yeast, the topoisomerase TOPII was not found to have an effect on CO interference in Arabidopsis but to facilitate interlocks resolution (remove interlacement of different bivalents at the time of synapsis) (Martinez-Garcia et al., 2018) that are normally all resolved by pachytene (Wang et al., 2009). Interestingly, TOPII is associated with the chromosome axis and accumulates in entangled regions during the zygotene stage (Martinez-Garcia et al., 2018). In Arabidopsis, a second noninterfering pathway of $\mathrm{CO}$ (called type III non-interfering $\mathrm{CO}$ in Figure 1), parallel to the MUS81 (type II) CO pathway, depends on FANCD2 and contributes to the formation of some non-interfering COs (Kurzbauer et al., 2018). The hotspots and coldspots of recombination are supposably due to the combined effects of chromatin features and the different anticrossover and crossover pathways. The relative mechanisms by which the $\mathrm{CO}$ rate is modulated at these sites still require further exploration. 


\section{EFFECTS OF GENOMIC REGIONS, CENTROMERE PAIRING, TELOMERE BOUQUET, AND REPEATED DNA RECOMBINATION}

Various genomic regions are known to have variable recombination rates in various plant species. New whole genome sequencing techniques have now given us a clear vision of the recombination maps at a fine scale in several plant species (Hellsten et al., 2013; Luo et al., 2019; Rowan et al., 2019). It is known that the genomic recombination rate is influenced by epigenetic marks, the genetic background (Sidhu et al., 2015; Ziolkowski et al., 2017; Dreissig et al., 2019; Lawrence et al., 2019), and the level of heterozygosity (Ziolkowski et al., 2015). It also greatly depends on chromatin structural variation where large inversion and translocations can suppress recombination (Rowan et al., 2019; Termolino et al., 2019). The molecular basis of this suppression is still unclear but probably involves the abnormal SC installation on unpaired chromatin loop domains.

Chromosome conformation changes are highly dynamic during meiotic prophase, involving active mechanisms to gather telomeres at the nuclear envelope (called telomere bouquet), centromere coupling, and chromosome pairing and synapsis (Sepsi and Schwarzacher, 2020; Lenykó-Thegze et al., 2021).

In maize and rice, the SUN proteins are involved in telomere bouquet formation (Murphy et al., 2014), synapsis, and CO formation (Zhang et al., 2020b). SUN1 and SUN2 Arabidopsis mutants delay the progression of meiosis, affect synapsis, and reduce the chiasma number (Varas et al., 2015). The role of AtSUN1 and AtSUN2 on the bouquet has not yet been analyzed since the Arabidopsis telomere bouquet was only recently defined using techniques that maintain the $3 \mathrm{D}$ structure of the nucleus intact (Hurel et al., 2018). In rice, the bouquet is dependent on the PAIR3/ASY3 AE element (Wang et al., 2011) and on the F-Box ZYGO protein that also affects the initiation of homologous pairing (Zhang F. et al., 2017). In maize, SPO11-1 foci are transiently observed on the nuclear periphery and seem excluded from the nucleolus ( $\mathrm{Ku}$ et al., 2020) suggesting a potential gathering of the DSBs machinery at the nuclear envelope and that its chromatin localization is not homogenous on the genome. Interestingly in Arabidopsis, the repetitive nucleolus organizing regions (NORs) acquired distinct chromatin characteristics during meiosis with strong ASY1 signals and the absence of the synaptic ZYP1 protein. The nucleolus employs an NHEJ mechanism requiring LIG4 (instead of the homologous recombination pathway dependent on RAD51) to repair the few DSBs produced in NORs and avoid unequal recombination in the repetitive recombinant DNA clusters (Sims et al., 2019). The presence of fewer COs in the heterochromatic repetitive knob region was observed cytogenetically in maize male meiocytes (Stack et al., 2017). However, by contrast to the nucleolus, knob meiotic recombination still uses the homologous recombination pathway as observed by the presence of MLH1 foci. This indicates that the diminution of meiotic recombination in distinctive heterochromatin regions probably uses several distinct mechanisms.

\section{EFFECTS OF AGE AND SEX ON MEIOTIC RECOMBINATION}

A moderate effect of the age of the shoot apical meristem on the number of CO was reported in Arabidopsis (Francis et al., 2007; Toyota et al., 2011; Li et al., 2017; Saini et al., 2020). Whether or not these age effects also occur in other plants is still unknown.

Sex difference in CO frequency is called heterochiasmy. In Arabidopsis, the $\mathrm{CO}$ number is higher in male meiocytes than in female meiocytes (Drouaud et al., 2007; Giraut et al., 2011; Saini et al., 2020). By sequencing Arabidopsis male and female backcrossed plants, 4.58 crossovers were found in male backcrossed compared to 3.08 in female backcrosses (CapillaPérez et al., 2021), noting that only half of the true CO number can be identified since gametes inherit a single chromatid and CO involves only two of the four chromatids of a bivalent. In Arabidopsis and maize, the difference is attributed to the length of the SC and the distribution of $\mathrm{CO}$ is also different in male and female meiocytes (Giraut et al., 2011; Kianian et al., 2018; Lloyd and Jenczewski, 2019; Luo et al., 2019). It was recently demonstrated that heterochiasmy is enforced in Arabidopsis by the SC central element ZYP1 (Capilla-Pérez et al., 2021). This suggests that heterochiasmy and SC length differences in male and female meiocytes are regulated by a common molecular pathway.

\section{EFFECT OF ENVIRONMENTAL CONDITIONS ON MEIOSIS}

In plants, meiosis occurs in flowers whose development was initiated via various past and present environmental clues (Antoniou-Kourounioti et al., 2021). The temperature variation is also known to modify the meiotic and somatic recombination rate using fluorescent-tagged lines (Francis et al., 2007; Li et al., 2017; Saini et al., 2017) correlated with cytological MLH1 foci counting (Lloyd et al., 2018). In Arabidopsis, both high $\left(28^{\circ} \mathrm{C}\right)$ and low $\left(8^{\circ} \mathrm{C}\right)$ temperature conditions increase meiotic recombination compared to medium temperature $\left(18^{\circ} \mathrm{C}\right)$. Interestingly, external temperatures are negatively correlated with the SC length that is itself correlated with the $\mathrm{CO}$ number. A correlation between SC length and $\mathrm{CO}$ number per chromosome was found (von Wettstein et al., 1984). Consequently, the longer SC length observed at low temperatures can explain the higher number of $\mathrm{CO}$ but not the increase of $\mathrm{CO}$ number observed at the higher temperatures. This increase in $\mathrm{CO}$ due to high temperature is not due to an increase in DSB formation as observed with $\gamma$ H2A.X and RAD51 foci. These extra COs are class I (ZMM) pathway as evidenced by increased MLH1 and HEI10 focus numbers in male meiocytes (Blary et al., 2018). Using mutants of different CO pathways in Arabidopsis, it was confirmed that the extra COs are derived from the interfering type I CO pathways and not to the type II (Modliszewski et al., 2018; De Storme and Geelen, 2020). The response of $\mathrm{CO}$ number to external temperature is not a universal stress response since saline stress does not affect it. Though the effect of temperature on COs was also observed and analyzed 
in barley, it seems that the mechanism of action is distinct. In contrast to Arabidopsis, the SC length in barley male meiocytes increases with higher temperature. The number of CO type I is not altered but their position shifted toward more internal non-telomeric regions as observed with cytologically mapped MLH3 foci (Phillips et al., 2015). The same effect of the position shifting from distal to more internal CO is also observed for some chromosome arms in wheat (Coulton et al., 2020). Though it seems an attractive and easy parameter that could modulate $\mathrm{CO}$ in crops, it appears that extremal temperatures have also other deleterious effects on the progression of meiosis such as defects of secondary division and wall formation reducing euploidy and seed set (De Storme et al., 2012; Draeger and Moore, 2017; De Storme and Geelen, 2020).

The presence of the histone H2A.Z was determined as the marker of the thermosensory response in Arabidopsis, with H2A.Z deposition decreasing with increasing temperatures (Kumar and Wigge, 2010). In addition, the CO sites overlap with the presence of H2A.Z nucleosome at gene promoters (Choi et al., 2013). Arabidopsis mutants of the H2A.Z placement show lower $\mathrm{CO}$ frequency. The correlation between H2A.Z and $\mathrm{CO}$ frequencies could explain the part of the effect of lower temperatures increasing $\mathrm{CO}$ frequency but not the effects of higher temperatures. Indeed, the higher $\mathrm{CO}$ frequency of Arabidopsis plants grown at $12^{\circ} \mathrm{C}$ compared to plants grown at $21^{\circ} \mathrm{C}$ disappears in mutants defective for H2A.Z deposition (Kumar and Wigge, 2010). The relation between the deposition of $\mathrm{H} 2 \mathrm{~A} . \mathrm{Z}$ and the phosphorylation of $\gamma \mathrm{H} 2 \mathrm{AX}$ associated with the formation of DSB is currently unknown.

Another key factor of this regulation of the meiotic recombination by temperature is the cyclin-dependent kinase CDKG1. Arabidopsis $c d k g 1$ mutants show temperature-sensitive meiotic defect at $23^{\circ} \mathrm{C}$ but not at $12^{\circ} \mathrm{C}$ with abnormally formed $\mathrm{SC}$, lower $\mathrm{CO}$ frequency, and reduce the bivalent number (Zheng et al., 2014; Nibau et al., 2020b). There are temperaturedependent isoforms of CDKG1 (Nibau et al., 2020a). These isoforms can interact with the spliceosome and can regulate the splicing of other spliceosome components and the Callose synthase 5 forming the pollen wall (Huang et al., 2013; Cavallari et al., 2018). It is still not known that whether or not the CDKG1-dependent temperature-sensitive regulation affects the production of different splicing variants of meiotic genes or affects $\mathrm{H} 2 \mathrm{~A} . \mathrm{Z}$ deposition.

Another meiotic cyclin CDKA; 1 has an important role in the regulation of the recombination landscape (Wijnker et al., 2019). CDKA;1 is also involved earlier in the germline fate decision via the inactivation of RBR1 (Chen et al., 2011; Zhao et al., 2017) pointing out the coordinating role of a peculiar meiotic $\mathrm{CDK}$ as a key factor for the meiotic fate and the regulation of meiotic recombination. What are the relative roles of the meiotic CDKs, the associated meiotic cyclins (such as SDS and TAM), and CDK inhibitors (KRPs) in the coordinated control of meiotic recombination in different temperature conditions remain to be analyzed.

Other factors such as climate, agrochemicals, heavy metals, combustible gasses, pharmaceuticals, and pathogens are known to modify meiosis in plants (Modliszewski and Copenhaver, 2017; Fuchs et al., 2018; Dreissig et al., 2019) but their mechanistic modes of action still need to be explored.

\section{CONCLUSION}

The understanding of several fundamental meiotic processes has strongly advanced during the past few years thanks to many studies in model and non-model plant species. Figure $\mathbf{1}$ summarizes the different proteins and functional modules known to be involved in the formation of bivalents.

The new techniques of isolated cell high throughput sequencing will revolutionize the questions we can ask about the dynamic meiotic chromosome conformation through prophase I.

Though controversial for many years, the divergence of several basic molecular meiotic mechanisms is now clear between different plant species. Achiasmatic inverted meiosis has also been reported in few non-model plants (Cabral et al., 2014; Heckmann et al., 2014; Hofstatter et al., 2021) underlining the extreme diversity of the plant meiotic programs. It contradicts the predictive expected assumptions based on phylogenetic relationships between plant species. In this perspective, one of the future challenges will be to identify the actual biochemical functions of the meiotic proteins not only based on the putative function supposed by the homology of conserved protein families. These interspecific differences are probably the real essence of the meiotic process that has evolved to bring genomic diversity. Even in the same species, there are known sex and cell to cell variability (Wang et al., 2019). It underlines the importance of studying directly meiosis in crops to manipulate it properly. Increasing our meiotic manipulation tools for improving plant breeding strategies is essential to cope with the challenge of feeding 10 billon humans by 2050 .

\section{AUTHOR CONTRIBUTIONS}

YGP and AR prepared and wrote the manuscript. JKGK and PR contributed to the survey of bibliographic references. All authors read and approved the final manuscript.

\section{FUNDING}

Relevant research in the Ronceret lab was supported by a grant from the Mexican SEP-CONACYT Ciencia Básica CB-20172018-A1-S-8496 to AR.

\section{ACKNOWLEDGMENTS}

We would like to thank Mathilde Grelon (INRAE, Versailles, France) and Wojtek Pawlowski (Cornell University, United States) for the critical reading of the manuscript. We would also like to thank the constructive suggestions of the three reviewers. We would like to apologize for the colleagues that have not been cited due to limitations of manuscript length. 


\section{REFERENCES}

Aklilu, B. B., Peurois, F., Saintomé, C., Culligan, K. M., Kobbe, D., Leasure, C., et al. (2020). Functional diversification of replication protein a paralogs and telomere length maintenance in Arabidopsis. Genetics 215, 989-1002. doi: 10.1534/genetics.120.303222

Antoniou-Kourounioti, R. L., Zhao, Y., Dean, C., and Howard, M. (2021). Feeling every bit of winter - distributed temperature sensitivity in vernalization. Front. Plant Sci. 12:628726. doi: 10.3389/fpls.2021.628726

Armstrong, S. J., Caryl, A. P., Jones, G. H., and Franklin, F. C. (2002). Asy1, a protein required for meiotic chromosome synapsis, localizes to axis-associated chromatin in Arabidopsis and Brassica. J. Cell Sci. 115, 3645-3655. doi: 10.1242/ jcs.00048

Balboni, M., Yang, C., Komaki, S., Brun, J., and Schnittger, A. (2020). COMET functions as a PCH2 Cofactor in regulating the HORMA domain Protein ASY1. Curr. Biol. 30, 4113-4127. doi: 10.1016/j.cub.2020.07.089

Barakate, A., Higgins, J. D., Vivera, S., Stephens, J., Perry, R. M., Ramsay, L., et al. (2014). The synaptonemal complex protein ZYP1 is required for imposition of meiotic crossovers in barley. Plant Cell. 26, 729-740. doi: 10.1105/tpc.113. 121269

Barakate, A., Orr, J., Schreiber, M., Colas, I., Lewandowska, D., McCallum, N., et al. (2021). Barley anther and meiocyte transcriptome dynamics in meiotic prophase I. Front. Plant Sci. 11:619404. doi: 10.3389/fpls.2020.619404

Benyahya, F., Nadaud, I., Da Ines, O., Rimbert, H., White, C., and Sourdille, P. (2020). SPO11.2 is essential for programmed double-strand break formation during meiosis in bread wheat (Triticum aestivum L.). Plant J. 104, 30-43. doi: $10.1111 /$ tpj. 14903

Biedermann, S., Harashima, H., Chen, P., Heese, M., Bouyer, D., Sofroni, K., et al. (2017). The retinoblastoma homolog RBR1 mediates localization of the repair protein RAD51 to DNA lesions in Arabidopsis. EMBO J. 36, 1279-1297. doi: 10.15252/embj.201694571

Blary, A., Gonzalo, A., Eber, F., Bérard, A., Bergès, H., Bessoltane, N., et al. (2018). FANCM limits meiotic crossovers in Brassica Crops. Front. Plant Sci. 9:368. doi: $10.3389 /$ fpls. 2018.00368

Blary, A., and Jenczewski, E. (2019). Manipulation of crossover frequency and distribution for plant breeding. Theor. Appl. Genet. 132, 575-592. doi: 10.1007/ s00122-018-3240-1

Bleuyard, J. Y., Gallego, M. E., and White, C. I. (2004). Meiotic defects in the Arabidopsis rad50 mutant point to conservation of the MRX complex function in early stages of meiotic recombination. Chromosoma 113, 197-203. doi: 10. 1007/s00412-004-0309-1

Bolaños-Villegas, P., and Argüello-Miranda, O. (2019). Meiosis research in orphan and non-orphan tropical crops. Front. Plant Sci. 10:74. doi: 10.3389/fpls.2019. 00074

Cabral, G., Marques, A., Schubert, V., Pedrosa-Harand, A., and Schlogelhofer, P. (2014). Chiasmatic and achiasmatic inverted meiosis of plants with holocentric chromosomes. Nat. Commun. 5:5070. doi: 10.1038/ncomms6070

Cai, X., Dong, F., Edelmann, R. E., and Makaroff, C. A. (2003). The Arabidopsis SYN1 cohesin protein is required for sister chromatid arm cohesion and homologous chromosome pairing. J. Cell Sci. 116, 2999-3007. doi: 10.1242/ jcs.00601

Capilla-Pérez, L., Durand, S., Hurel, A., Lian, Q., Chambon, A., Taochy, C., et al. (2021). The synaptonemal complex imposes crossover interference and heterochiasmy in Arabidopsis. Proc. Natl. Acad. Sci. U.S.A. 118, e2023613118. doi: $10.1073 /$ pnas.2023613118

Cavallari, N., Nibau, C., Fuchs, A., Dadarou, D., Barta, A., and Doonan, J. H. (2018). The cyclin-dependent kinase G group defines a thermosensitive alternative splicing circuit modulating the expression of Arabidopsis ATU2AF65A. Plant J. 94, 1010-1022. doi: 10.1111/tpj.13914

Chambon, A., West, A., Vezon, D., Horlow, C., De Muyt, A., Chelysheva, L., et al. (2018). Identification of ASYNAPTIC4, a component of the meiotic chromosome axis. Plant Physiol. 178, 233-246. doi: 10.1104/pp.17.01725

Chan, A., and Cande, W. Z. (1998). Maize meiotic spindles assemble around chromatin and do not require paired chromosomes. J. Cell Sci. 111, 3507-3515. doi: $10.1242 /$ jcs.111.23.3507

Che, L., Tang, D., Wang, K., Wang, M., Zhu, K., Yu, H., et al. (2011). OsAM1 is required for leptotene-zygotene transition in rice. Cell Res. 21, 654-665. doi: $10.1038 / \mathrm{cr} .2011 .7$
Che, L., Wang, K., Tang, D., Liu, Q., Chen, X., Li, Y., et al. (2014). OsHUS1 Facilitates Accurate Meiotic Recombination in Rice. PLoS Genetics. 10:e1004405. doi: 10.1371/journal.pgen. 1004405

Chelysheva, L., Diallo, S., Vezon, D., Gendrot, G., Vrielynck, N., Belcram, K., et al. (2005). AtREC8 and AtSCC3 are essential to the monopolar orientation of the kinetochores during meiosis. J. Cell Sci. 118, 4621-4632. doi: 10.1242/jcs.0 2583

Chelysheva, L., Grandont, L., Vrielynck, N., le Guin, S., Mercier, R., and Grelon, M. (2010). An easy protocol for studying chromatin and recombination protein dynamics during Arabidopsis thaliana meiosis: immunodetection of cohesins, histones and MLH1. Cytogenet. Genome Res. 129, 143-153. doi: 10.1159/ 000314096

Chelysheva, L., Vezon, D., Belcram, K., Gendrot, G., and Grelon, M. (2008). The Arabidopsis BLAP75/Rmi homologue plays crucial roles in meiotic doublestrand break repair. PLoS Genet. 4:e1000309. doi: 10.1371/journal.pgen.100 0309

Chelysheva, L., Vezon, D., Chambon, A., Gendrot, G., Pereira, L., Lemhemdi, A., et al. (2012). The Arabidopsis HEI10 is a new ZMM protein related to Zip3. PLoS Genet. 8:e1002799. doi: 10.1371/journal.pgen.1002799

Chelysheva, L. A., Gendrot, G., Vezon, D., Doutriaux, M. P., Mercier, R., and Grelon, M. (2007). Zip4/Spo22 is required for class I CO formation but not for synapsis completion in Arabidopsis thaliana. PLoS Genet. 3:e83. doi: 10.1371/ journal.pgen.0030083

Chen, Z., Higgins, J. D., Hui, J. T. L., Li, J., Franklin, F. C. H., and Berger, F. (2011). Retinoblastoma protein is essential for early meiotic events in Arabidopsis. EMBO J. 30, 744-755. doi: 10.1038/emboj.2010.344

Chen, Z., Zhangh, W., Timofejeva, L., Gerardin, Y., and Ma, H. (2005). The Arabidopsis ROCK-N-ROLLERS gene encodes a homolog of the yeast ATP-dependent DNA helicase MER3 and is required for normal meiotic crossover formation. Plant J. 43, 321-334. doi: 10.1111/j.1365-313x.2005.0 2461.x

Choi, K., Zhao, X., Kelly, K. A., Venn, O., Higgins, J. D., Yelina, N. E., et al. (2013). Arabidopsis meiotic crossover hot spots overlap with H2A.Z nucleosomes at gene promoters. Nat. Genet. 45, 1327-1336.

Choi, K., Zhao, X., Tock, A. J., Lambing, C., Underwood, C. J., Hardcastle, T. J., et al. (2018). Nucleosomes and DNA methylation shape meiotic DSB frequency in Arabidopsis thaliana transposons and gene regulatory regions. Genome Res. 28, 532-546. doi: 10.1101/gr.225599.117

Cifuentes, M., Eber, F., Lucas, M.-O., Lode, M., Chèvre, A.-M., and Jenczewski, E. (2010). Repeated polyploidy drove different levels of crossover suppression between homoeologous chromosomes in Brassica napus allohaploids. Plant Cell 22, 2265-2276.

Colas, I., Barakate, A., Macaulay, M., Schreiber, M., Stephens, J., Vivera, S., et al. (2019). desynaptic5 carries a spontaneous semi-dominant mutation affecting Disrupted Meiotic cDNA 1 in barley. J. Exp. Bot. 70, 2683-2698. doi: 10.1093/ jxb/erz080

Colas, I., Macaulay, M., Higgins, J. D., Phillips, D., Barakate, A., Posch, M., et al. (2016). A spontaneous mutation in MutL-Homolog 3 (HvMLH3) affects synapsis and crossover resolution in the barley desynaptic mutant des10. New Phytol. 212, 693-707. doi: 10.1111/nph.14061

Coulton, A., Burridge, A. J., and Edwards, K. J. (2020). Examining the effects of temperature on recombination in wheat. Front. Plant Sci. 11:230. doi: 10.3389/ fpls.2020.00230

Couteau, F., Belzile, F., Horlow, C., Grandjean, O., Vezon, D., and Doutriaux, M. P. (1999). Random chromosome segregation without meiotic arrest in both male and female meiocytes of a dmc1 mutant of Arabidopsis. Plant Cell 11, 1623-1634. doi: 10.1105/tpc.11.9.1623

Crismani, W., Girard, C., Froger, N., Pradillo, M., Santos, J. L., Chelysheva, L., et al. (2012). FANCM limits meiotic crossovers. Science 336, 1588-1590. doi: 10.1126/science. 1220381

Cromer, L., Jolivet, S., Singh, D. K., Berthier, F., De Winne, N., De Jaeger, G., et al. (2019). Patronus is the elusive plant securin, preventing chromosome separation by antagonizing separase. Proc. Natl. Acad. Sci. U.S.A. 116, 1601816027. doi: 10.1073/pnas.1906237116

Da Ines, O., Degroote, F., Goubely, C., Amiard, S., Gallego, M. E., and White, C. I. (2013). Meiotic recombination in Arabidopsis is catalysed by DMC1, with RAD51 playing a supporting role. PLoS Genet. 9:e1003787. doi: 10.1371/journal. pgen. 1003787 
Da Ines, O., Michard, R., Fayos, I., Bastianelli, G., Nicolas, A., Guiderdoni, E., et al. (2020). Bread wheat TaSPO11-1 exhibits evolutionarily conserved function in meiotic recombination across distant plant species. Plant J. 103, 2052-2068. doi: $10.1111 /$ tpj.14882

Dangel, N. J., Knoll, A., and Puchta, H. (2014). MHF1 plays Fanconi anaemia complementation group $\mathrm{M}$ protein (FANCM)-dependent and FANCMindependent roles in DNA repair and homologous recombination in plants. Plant J. 78, 822-833. doi: 10.1111/tpj.12507

Darrier, B., Arrieta, M., Mittmann, S. U., Sourdille, P., Ramsay, L., Waugh, R., et al. (2020). "Following the formation of synaptonemal complex formation in wheat and barley by high-resolution microscopy," in Plant Meiosis: Methods and Protocols, eds M. Pradillo and S. Heckmann (New York, NY: Springer New York), 207-215. doi: 10.1007/978-1-4939-9818-0_15

De, K., Sterle, L., Krueger, L., Yang, X., and Makaroff, C. A. (2014). Arabidopsis thaliana WAPL Is essential for the prophase removal of cohesin during meiosis. PLoS Genet. 10:e1004497. doi: 10.1371/journal.pgen.1004497

De Muyt, A., Pereira, L., Vezon, D., Chelysheva, L., Gendrot, G., Chambon, A., et al. (2009). A high throughput genetic screen identifies new early meiotic recombination functions in Arabidopsis thaliana. PLoS Genet. 5:e1000654. doi: 10.1371/journal.pgen.1000654

De Muyt, A., Vezon, D., Gendrot, G., Gallois, J. L., Stevens, R., and Grelon, M. (2007). AtPRD1 is required for meiotic double strand break formation in Arabidopsis thaliana. EMBO J. 26, 4126-4137. doi: 10.1038/sj.emboj.7601815

De Storme, N., Copenhaver, G. P., and Geelen, D. (2012). Production of diploid male gametes in Arabidopsis by cold-induced destabilization of postmeiotic radial microtubule arrays. Plant Physiol. 160, 1808-1826. doi: 10.1104/pp.112. 208611

De Storme, N., and Geelen, D. (2020). High temperatures alter cross-over distribution and induce male meiotic restitution in Arabidopsis thaliana. Commun. Biol. 3, 187-187.

Desjardins, S. D., Ogle, D. E., Ayoub, M. A., Heckmann, S., Henderson, I. R., Edwards, K. J., et al. (2020). MutS homologue 4 and MutS homologue 5 maintain the obligate crossover in wheat despite stepwise gene loss following polyploidization. Plant Physiol. 183, 1545-1558. doi: 10.1104/pp.20.00534

Draeger, T., Martin, C. A., Alabdullah, A. K., Pendle, A., Rey, M.-D., Shaw, P., et al. (2020). Dmcl is a candidate for temperature tolerance during wheat meiosis. Theor. Appl. Genet. 133, 809-828. doi: 10.1007/s00122-019-03508-9

Draeger, T., and Moore, G. (2017). Short periods of high temperature during meiosis prevent normal meiotic progression and reduce grain number in hexaploid wheat (Triticum aestivum L.). Theor. Appl. Genet. 130, 1785-1800. doi: 10.1007/s00122-017-2925-1

Dray, E., Siaud, N., Dubois, E., and Doutriaux, M. P. (2006). Interaction between Arabidopsis Brca2 and its partners Rad51, Dmc1, and Dss1. Plant Physiol. 140, 1059-1069. doi: 10.1104/pp.105.075838

Dreissig, S., Mascher, M., and Heckmann, S. (2019). Variation in recombination rate is shaped by domestication and environmental conditions in barley. Mol. Biol. Evol. 36, 2029-2039. doi: 10.1093/molbev/msz141

Drouaud, J., Mercier, R., Chelycheva, L., Bérard, A., Falque, A., Martin, O., et al. (2007). Sex-specific crossover distributions and variations in interference level along Arabidopsis thaliana chromosome 4. PLoS Genet. 3:e106. doi: 10.1371/ journal.pgen.0030106

Dukowic-Schulze, S., Garcia, N., Shunmugam, A. S. K., Kagale, S., and Chen, C. (2020). "Isolating male meiocytes from maize and wheat for “-Omics" analyses," in Plant Meiosis: Methods and Protocols, eds M. Pradillo and S. Heckmann (New York, NY: Springer New York), 237-258. doi: 10.1007/978-1-4939-98180_17

Dukowic-Schulze, S., Sundararajan, A., Ramaraj, T., Kianian, S., Pawlowski, W. P., Mudge, J., et al. (2016). Novel meiotic miRNAs and indications for a role of PhasiRNAs in meiosis. Front. Plant Sci. 7:762. doi: 10.3389/fpls.2016.00762

Edlinger, B., and Schlögelhofer, P. (2011). Have a break: determinants of meiotic DNA double strand break (DSB) formation and processing in plants. J. Exp. Bot. 62, 1545-1563. doi: 10.1093/jxb/erq421

Escobar-Guzman, R., Rodriguez-Leal, D., Vielle-Calzada, J.-P., and Ronceret, A. (2015). Whole-mount immunolocalization to study female meiosis in Arabidopsis. Nat. Protocols 10, 1535-1542. doi: 10.1038/nprot.2015.098

Ferdous, M., Higgins, J. D., Osman, K., Lambing, C., Roitinger, E., Mechtler, K., et al. (2012). Inter-homolog crossing-over and synapsis in Arabidopsis meiosis are dependent on the chromosome axis protein AtASY3. PLoS Genet. 8:e1002507. doi: 10.1371/journal.pgen.1002507

Fernandes, J. B., Duhamel, M., Seguéla-Arnaud, M., Froger, N., Girard, C., Choinard, S., et al. (2018a). FIGL1 and its novel partner FLIP form a conserved complex that regulates homologous recombination. PLoS Genet. 14:e1007317. doi: 10.1371/journal.pgen.1007317

Fernandes, J. B., Séguéla-Arnaud, M., Larchevêque, C., Lloyd, A. H., and Mercier, R. (2018b). Unleashing meiotic crossovers in hybrid plants. Proc. Natl. Acad. Sci. U.S.A. 115, 2431-2436.

Fernandes, J. B., Wlodzimierz, P., and Henderson, I. R. (2019). Meiotic recombination within plant centromeres. Curr. Opin. Plant Biol. 48, 26-35. doi: 10.1016/j.pbi.2019.02.008

Flórez-Zapata, N. M. V., Reyes-Valdés, M. H., and Martínez, O. (2016). Long noncoding RNAs are major contributors to transcriptome changes in sunflower meiocytes with different recombination rates. BMC Genomics 17:490. doi: 10 . 1186/s12864-016-2776-1

France, M. G., Enderle, J., Röhrig, S., Puchta, H., Franklin, F. C. H., and Higgins, J. D. (2021). ZYP1 is required for obligate cross-over formation and crossover interference in Arabidopsis. Proc. Natl. Acad Sci. U.S.A. 118:e2021671118. doi: $10.1073 /$ pnas. 2021671118

Francis, K. E., Lam, S. Y., Harrison, B. D., Bey, A. L., Berchowitz, L. E., and Copenhaver, G. P. (2007). Pollen tetrad-based visual assay for meiotic recombination in Arabidopsis. Proc. Natl. Acad Sci. U.S.A. 104, 3913-3918. doi: 10.1073/pnas.0608936104

Fu, M., Wang, C., Xue, F., Higgins, J., Chen, M., Zhang, D., et al. (2016). The DNA topoisomerase VIB Subunit OsMTOPVIB is essential for meiotic recombination initiation in rice. Mol. Plant 9, 1539-1541. doi: 10.1016/j.molp. 2016.07.006

Fu, R., Wang, C., Shen, H., Zhang, J., Higgins, J. D., and Liang, W. (2020). Rice OsBRCA2 is required for DNA double-strand break repair in meiotic cells. Front. Plant Sci. 11:600820. doi: 10.3389/fpls.2020.600820

Fuchs, L. K., Jenkins, G., and Phillips, D. W. (2018). Anthropogenic impacts on meiosis in plants. Front. Plant Sci. 9:1429. doi: 10.3389/fpls.2018.01429

Geuting, V., Kobbe, D., Hartung, F., Dürr, J., Focke, M., and Puchta, H. (2009). Two distinct MUS81-EME1 complexes from Arabidopsis process holliday junctions. Plant Physiol. 150, 1062-1071. doi: 10.1104/pp.109.136846

Girard, C., Chelysheva, L., Choinard, S., Froger, N., Macaisne, N., Lehmemdi, A., et al. (2015). AAA-ATPase FIDGETIN-LIKE 1 and helicase FANCM antagonize meiotic crossovers by distinct mechanisms. PLoS Genet. 11:e1005369. doi: 10. 1371/journal.pgen.1005369

Girard, C., Crismani, W., Froger, N., Mazel, J., Lemhemdi, A., Horlow, C., et al. (2014). FANCM-associated proteins MHF1 and MHF2, but not the other Fanconi anemia factors, limit meiotic crossovers. Nucleic Acids Res. 42, $9087-$ 9095. doi: 10.1093/nar/gku614

Giraut, L., Falque, M., Drouaud, J., Pereira, L., Martin, O. C., and Mézard, C. (2011). Genome-wide crossover distribution in Arabidopsis thaliana meiosis reveals sex-specific patterns along chromosomes. PLoS Genet. 7:e1002354. doi: 10.1371/journal.pgen.1002354

Golicz, A. A., Bhalla, P. L., Edwards, D., and Singh, M. B. (2020). Rice 3D chromatin structure correlates with sequence variation and meiotic recombination rate. Commun. Biol. 3:235.

Gonzalo, A., Lucas, M.-O., Charpentier, C., Sandmann, G., Lloyd, A., and Jenczewski, E. (2019). Reducing MSH4 copy number prevents meiotic crossovers between non-homologous chromosomes in Brassica napus. Nat. Commun. 10:2354.

Gordillo, S. V. G., Escobar-Guzman, R., Rodriguez-Leal, D., Vielle-Calzada, J.P., and Ronceret, A. (2020). "Whole-mount immunolocalization procedure for plant female meiocytes," in Plant Meiosis: Methods and Protocols, eds M. Pradillo and S. Heckmann (New York, NY: Springer New York), 13-24. doi: 10.1007/978-1-4939-9818-0_2

Grelon, M., Vezon, D., Gendrot, G., and Pelletier, G. (2001). AtSPO11-1 is necessary for efficient meiotic recombination in plants. EMBO J. 20, 589-600. doi: 10.1093/emboj/20.3.589

Grey, C., and de Massy, B. (2021). Chromosome organization in early meiotic prophase. Front. Cell Dev. Biol. 9:688878. doi: 10.3389/fcell.2021.688878

Hartung, F., Suer, S., Knoll, A., Wurz-Wildersinn, R., and Puchta, H. (2008). Topoisomerase 3 alpha and RMI1 suppress somatic crossovers and are essential 
for resolution of meiotic recombination intermediates in Arabidopsis thaliana. PLoS Genet. 4:e1000285. doi: 10.1371/journal.pgen.1000285

Hartung, F., Suer, S., and Puchta, H. (2007a). Two closely related RecQ helicases have antagonistic roles in homologous recombination and DNA repair in Arabidopsis thaliana. Proc. Natl. Acad. Sci. U.S.A. 104, 18836-18841. doi: 10.1073/pnas.0705998104

Hartung, F., Wurz-Wildersinn, R., Fuchs, J., Schubert, I., Suer, S., and Puchta, H. (2007b). The catalytically active tyrosine residues of both SPO11-1 and SPO112 are required for meiotic double-strand break induction in Arabidopsis. Plant Cell 19, 3090-3099. doi: 10.1105/tpc.107.054817

He, Y., Wang, M., Dukowic-Schulze, S., Zhou, A., Tiang, C.-L., Shilo, S., et al. (2017). Genomic features shaping the landscape of meiotic double-strand-break hotspots in maize. Proc. Natl. Acad. Sci. U.S.A. 114, 12231-12236. doi: 10.1073/ pnas. 1713225114

Heckmann, S., Jankowska, M., Schubert, V., Kumke, K., Ma, W., and Houben, A. (2014). Alternative meiotic chromatid segregation in the holocentric plant Luzula elegans. Nat. Commun. 5:4979.

Hellsten, U., Wright, K. M., Jenkins, J., Shu, S., Yuan, Y., Wessler, S. R., et al. (2013). Fine-scale variation in meiotic recombination in Mimulus inferred from population shotgun sequencing. Proc. Natl. Acad. Sci. U.S.A. 110, 19478-19482. doi: $10.1073 /$ pnas. 1319032110

Higgins, J. D., Armstrong, S. J., Franklin, F. C., and Jones, G. H. (2004). The Arabidopsis MutS homolog AtMSH4 functions at an early step in recombination: Evidence for two classes of recombination in Arabidopsis. Genes Dev. 18, 2557-2570. doi: 10.1101/gad.317504

Higgins, J. D., Buckling, E. F., Franklin, F. C., and Jones, G. H. (2008a). Expression and functional analysis of AtMUS81 in Arabidopsis meiosis reveals a role in the second pathway of crossing-over. Plant J. 54, 152-162. doi: 10.1111/j.1365313x.2008.03403.x

Higgins, J. D., Ferdous, M., Osman, K., and Franklin, F. C. (2011). The RecQ helicase AtRECQ4A is required to remove inter-chromosomal telomeric connections that arise during meiotic recombination in Arabidopsis. Plant J. 65, 492-502. doi: 10.1111/j.1365-313X.2010.04438.x

Higgins, J. D., Sanchez-Moran, E., Armstrong, S. J., Jones, G. H., and Franklin, F. C. H. (2005). The Arabidopsis synaptonemal complex protein ZYP1 is required for chromosome synapsis and normal fidelity of crossing over. Genes Dev. 19, 2488-2500. doi: 10.1101/gad.354705

Higgins, J. D., Vignard, J., Mercier, R., Pugh, A. G., Franklin, F. C., and Jones, G. H. (2008b). AtMSH5 partners AtMSH4 in the class I meiotic crossover pathway in Arabidopsis thaliana, but is not required for synapsis. Plant J. 55, 28-39. doi: $10.1111 / \mathrm{j} .1365-313 x .2008 .03470 . \mathrm{x}$

Hofstatter, P. G., Thangavel, G., Castellani, M., and Marques, A. (2021). Meiosis progression and recombination in holocentric plants: what is known? Front. Plant Sci. 12:658296. doi: 10.3389/fpls.2021.658296

Hu, Q., Li, Y., Wang, H., Shen, Y., Zhang, C., Du, G., et al. (2017). Meiotic chromosome association 1 interacts with TOP $3 \alpha$ and regulates meiotic recombination in rice. Plant Cell 29, 1697-1708. doi: 10.1105/tpc.17.00241

Hu, Q., Tang, D., Wang, H., Shen, Y., Chen, X., Ji, J., et al. (2016). The exonuclease homolog OsRAD1 promotes accurate meiotic double-strand break repair by suppressing nonhomologous end joining. Plant Physiol. 172, 1105-1116.

Hu, Q., Zhang, C., Xue, Z., Ma, L., Liu, W., Shen, Y., et al. (2018). OsRAD17 is required for meiotic double-strand break repair and plays a redundant role with OsZIP4 in synaptonemal complex assembly. Front. Plant Sci. 9:1236. doi: 10.3389/fpls.2018.01236

Huang, J., Cheng, Z., Wang, C., Hong, Y., Su, H., Wang, J., et al. (2015). Formation of interference-sensitive meiotic cross-overs requires sufficient DNA leadingstrand elongation. Proc. Natl. Acad. Sci. U.S.A. 112, 12534-12539. doi: 10.1073/ pnas. 1507165112

Huang, J., Wang, C., Li, X., Fang, X., Huang, N., Wang, Y., et al. (2020). Conservation and divergence in the meiocyte sRNAomes of Arabidopsis, soybean, and cucumber. Plant Physiol. 182, 301-317. doi: 10.1104/pp.19.00807

Huang, J., Wang, C., Wang, H., Lu, P., Zheng, B., Ma, H., et al. (2019). Meiocytespecific and AtSPO11-1-dependent small RNAs and their association with meiotic gene expression and recombination. Plant Cell 31, 444-464. doi: 10. $1105 /$ tpc. 18.00511

Huang, X.-Y., Niu, J., Sun, M.-X., Zhu, J., Gao, J.-F., Yang, J., et al. (2013). CYCLINDEPENDENT KINASE G1 Is Associated with the spliceosome to Regulate
CALLOSE SYNTHASE5 splicing and pollen wall formation in Arabidopsis. Plant Cell 25, 637-648. doi: 10.1105/tpc.112.107896

Hurel, A., Phillips, D., Vrielynck, N., Mézard, C., Grelon, M., and Christophorou, N. (2018). A cytological approach to studying meiotic recombination and chromosome dynamics in Arabidopsis thaliana male meiocytes in three dimensions. Plant J. 95, 385-396. doi: 10.1111/tpj.13942

Iglesias, F. M., Bruera, N. A., Dergan-Dylon, S., Marino-Buslje, C., Lorenzi, H., Mateos, J. L., et al. (2015). The Arabidopsis DNA polymerase $\delta$ has a role in the deposition of transcriptionally active epigenetic marks, development and flowering. PLoS Genet. 11:e1004975. doi: 10.1371/journal.pgen.1004975

Ji, J., Tang, D., Shen, Y., Xue, Z., Wang, H., Shi, W., et al. (2016). P31comet, a member of the synaptonemal complex, participates in meiotic DSB formation in rice. Proc. Natl. Acad. Sci. U.S.A. 113, 10577-10582. doi: 10.1073/pnas. 1607334113

Jing, J., Zhang, T., Wang, Y., Cui, Z., and He, Y. (2019). ZmRAD51C is essential for double-strand break repair and homologous recombination in maize meiosis. Int. J. Mol. Sci. 20:5513. doi: 10.3390/ijms20215513

Jing, J.-L., Zhang, T., Kao, Y.-H., Huang, T.-H., Wang, C.-J. R., and He, Y. (2020). ZmMTOPVIB enables DNA double-strand break formation and bipolar spindle assembly during maize meiosis. Plant Physiol. 184, 1811-1822. doi: 10.1104/pp.20.00933

Jolivet, S., Vezon, D., Froger, N., and Mercier, R. (2006). Non conservation of the meiotic function of the Ski8/Rec103 homolog in Arabidopsis. Genes Cells 11, 615-622. doi: 10.1111/j.1365-2443.2006.00972.x

Kelliher, T., and Walbot, V. (2012). Hypoxia triggers meiotic fate acquisition in maize. Science 337, 345-348. doi: 10.1126/science. 1220080

Kianian, P. M. A., Wang, M., Simons, K., Ghavami, F., He, Y., Dukowic-Schulze, S., et al. (2018). High-resolution crossover mapping reveals similarities and differences of male and female recombination in maize. Nat. Commun. 9:2370.

Kim, J., and Choi, K. (2019). Signaling-mediated meiotic recombination in plants. Curr. Opin. Plant Biol. 51, 44-50. doi: 10.1016/j.pbi.2019.04.001

Komiya, R., Ohyanagi, H., Niihama, M., Watanabe, T., Nakano, M., Kurata, N., et al. (2014). Rice germline-specific Argonaute MEL1 protein binds to phasiRNAs generated from more than 700 lincRNAs. Plant J. 78, 385-397. doi: $10.1111 /$ tpj.1248

Ku, J.-C., Ronceret, A., Golubovskaya, I., Lee, D. H., Wang, C., Timofejeva, L., et al. (2020). Dynamic localization of SPO11-1 and conformational changes of meiotic axial elements during recombination initiation of maize meiosis. PLoS Genet. 16:e1007881. doi: 10.1371/journal.pgen.1007881

Kumar, R., Duhamel, M., Coutant, E., Ben-Nahia, E., and Mercier, R. (2019). Antagonism between BRCA2 and FIGL1 regulates homologous recombination. Nucleic Acids Res. 47, 5170-5180. doi: 10.1093/nar/gkz225

Kumar, S. V., and Wigge, P. A. (2010). H2A.Z-containing nucleosomes mediate the thermosensory response in Arabidopsis. Cell 140, 136-147. doi: 10.1016/j.cell. 2009.11.006

Kuo, P., Da Ines, O., and Lambing, C. (2021). Rewiring meiosis for crop improvement. Front. Plant Sci. 12:708948. doi: 10.3389/fpls.2021.708948

Kurzbauer, M. T., Janisiw, M. P., Paulin, L. F., Prusén Mota, I., Tomanov, K., Krsicka, O., et al. (2021). ATM controls meiotic DNA double-strand break formation and recombination and affects synaptonemal complex organization in plants. Plant Cell 33, 1633-1656. doi: 10.1093/plcell/koab045

Kurzbauer, M.-T., Pradillo, M., Kerzendorfer, C., Sims, J., Ladurner, R., Oliver, C., et al. (2018). Arabidopsis thaliana FANCD2 promotes meiotic crossover formation. Plant Cell 30, 415-428. doi: 10.1105/tpc.17.00745

Kurzbauer, M. T., Uanschou, C., Chen, D., and Schlogelhofer, P. (2012). The recombinases DMC1 and RAD51 are functionally and spatially separated during meiosis in Arabidopsis. Plant Cell 24, 2058-2070. doi: 10.1105/tpc.112. 098459

Lambing, C., Franklin, F. C. H., and Wang, C.-J. R. (2017). Understanding and manipulating meiotic recombination in plants. Plant Physiol. 173, 1530-1542. doi: $10.1104 /$ pp.16.01530

Lambing, C., Kuo, P. C., Tock, A. J., Topp, S. D., and Henderson, I. R. (2020a). ASY1 acts as a dosage-dependent antagonist of telomere-led recombination and mediates crossover interference in Arabidopsis. Proc. Natl. Acad. Sci. U.S.A. 117, 13647-13658. doi: 10.1073/pnas.1921055117

Lambing, C., Osman, K., Nuntasoontorn, K., West, A., Higgins, J. D., Copenhaver, G. P., et al. (2015). Arabidopsis PCH2 mediates meiotic chromosome 
remodeling and maturation of crossovers. PLoS Genet. 11:e1005372. doi: 10. 1371/journal.pgen.1005372

Lambing, C., Tock, A. J., Topp, S. D., Choi, K., Kuo, P. C., Zhao, X., et al. (2020b). Interacting genomic landscapes of REC8-cohesin, chromatin, and meiotic recombination in Arabidopsis. Plant Cell 32, 1218-1239. doi: 10.1105/ tpc. 19.00866

Lawrence, E. J., Gao, H., Tock, A. J., Lambing, C., Blackwell, A. R., Feng, X., et al. (2019). Natural variation in TBP-ASSOCIATED FACTOR $4 \mathrm{~b}$ controls meiotic crossover and germline transcription in Arabidopsis. Curr. Biol. 29, 2676-2686. doi: 10.1016/j.cub.2019.06.084

Lee, D. H., Kao, Y.-H., Ku, J.-C., Lin, C.-Y., Meeley, R., Jan, Y.-S., et al. (2015). The axial element protein DESYNAPTIC2 mediates meiotic double-strand break formation and synaptonemal complex assembly in maize. Plant Cell 27, 2516-2529. doi: 10.1105/tpc.15.00434

Lenykó-Thegze, A., Fábian, A., Mihók, E., Makai, D., and Cseh, A. (2021). Pericentromeric chromatin reorganisation follows the initiation of recombination and coincides with early events of synapsis in cereals. Plant J. doi: 10.1111/tpj.15391 [Epub ahead of print].

Li, F., De Storme, N., and Geelen, D. (2017). Dynamics of male meiotic recombination frequency during plant development using fluorescent tagged lines in Arabidopsis thaliana. Sci. Rep. 7:42535.

Li, W., Chen, C., Markmann-Mulisch, U., Timofejeva, L., Schmelzer, E., Ma, H., et al. (2004). The Arabidopsis AtRAD51 gene is dispensable for vegetative development but required for meiosis. Proc. Natl. Acad. Sci. U.S.A. 101, 1059610601. doi: 10.1073/pnas.0404110101

Li, X., Chang, Y., Xin, X., Zhu, C., Li, X., Higgins, J. D., et al. (2013). Replication protein $\mathrm{A} 2 \mathrm{c}$ coupled with replication protein A1c regulates crossover formation during meiosis in rice. Plant Cell 25, 3885-3899. doi: 10.1105/tpc.113. 118042

Li, X., Yu, M., Bolaños-Villegas, P., Zhang, J., Ni, D., Ma, H., et al. (2021). Fanconi anemia ortholog FANCM regulates meiotic crossover distribution in plants. Plant Physiol. 186, 344-360. doi: 10.1093/plphys/kiab061

Li, Y., Qin, B., Shen, Y., Zhang, F., Liu, C., You, H., et al. (2018). HEIP1 regulates crossover formation during meiosis in rice. Proc. Natl. Acad. Sci. U.S.A. 115, 10810-10815. doi: 10.1073/pnas. 1807871115

Liu, H., Cao, A., Yang, L., and Wang, J. (2020). "Rice female meiosis: genome-wide mRNA, small RNA, and DNA methylation analysis during ovule development," in Plant Meiosis: Methods and Protocols, eds M. Pradillo and S. Heckmann (New York, NY: Springer New York), 267-280. doi: 10.1007/978-1-4939-98180_19

Liu, H., and Nonomura, K. I. (2016). A wide reprogramming of histone H3 modifications during male meiosis $\mathrm{I}$ in rice is dependent on the Argonaute protein MEL1. J. Cell Sci. 129, 3553-3561. doi: 10.1242/jcs.184937

Lloyd, A., and Jenczewski, E. (2019). Modelling sex-specific crossover patterning in Arabidopsis. Genetics 211, 847-859. doi: 10.1534/genetics.118.30 1838

Lloyd, A., Morgan, C., Franklin, C., and Bomblies, K. (2018). Plasticity of meiotic recombination rates in response to temperature in Arabidopsis. Genetics 208, 1409-1420. doi: 10.1534/genetics.117.300588

Lohmiller, L. D., de Muyt, A., Howard, B., Offenberg, H. H., Heyting, C., Grelon, M., et al. (2008). Cytological analysis of MRE11 protein during early meiotic prophase I in Arabidopsis and tomato. Chromosoma 117, 277-288. doi: 10. 1007/s00412-007-0147-z

Long, J., Walker, J., She, W., Aldridge, B., Gao, H., Deans, S., et al. (2021). Nurse cell-derived small RNAs define paternal epigenetic inheritance in Arabidopsis. Science 373:eabh0556. doi: 10.1126/science.abh0556

Lu, J., Wang, C., Wang, H., Zheng, H., Bai, W., Lei, D., et al. (2020). OsMFS1/OsHOP2 complex participates in rice male and female development. Front. Plant Sci. 11:518. doi: 10.3389/fpls.2020.00518

Luo, C., Li, X., Zhang, Q., and Yan, J. (2019). Single gametophyte sequencing reveals that crossover events differ between sexes in maize. Nat. Commun. 10:785.

Luo, Q., Li, Y., Shen, Y., and Cheng, Z. (2014). Ten years of gene discovery for meiotic event control in rice. J. Genet. Genomics 41, 125-137. doi: 10.1016/j. jgg.2014.02.002

Macaisne, N., Novatchkova, M., Peirera, L., Vezon, D., Jolivet, S., Froger, N., et al. (2008). SHOC1, an XPF endonuclease-related protein, is essential for the formation of class I meiotic crossovers. Curr. Biol. 18, 1432-1437. doi: 10.1016/j.cub.2008.08.041
Macaisne, N., Vignard, J., and Mercier, R. (2011). SHOC1 and PTD form an XPFERCC1-like complex that is required for formation of class I crossovers. J. Cell Sci. 124, 2687-2691. doi: 10.1242/jcs.088229

Martinez-Garcia, M., Schubert, V., Osman, K., Darbyshire, A., Sanchez-Moran, E., and Franklin, F. C. H. (2018). TOPII and chromosome movement help remove interlocks between entangled chromosomes during meiosis. J. Cell Biol. 217, 4070-4079. doi: 10.1083/jcb.201803019

Mason, A. S., and Wendel, J. F. (2020). Homoeologous exchanges, segmental allopolyploidy, and polyploid genome evolution. Front. Genet. 11:1014. doi: $10.3389 /$ fgene.2020.01014

Melamed-Bessudo, C., Shilo, S., and Levy, A. A. (2016). Meiotic recombination and genome evolution in plants. Curr. Opin. Plant Biol. 30, 82-87. doi: 10.1016/j. pbi.2016.02.003

Mercier, R., Jolivet, S., Vezon, D., Huppe, E., Chelysheva, L., Giovanni, M., et al. (2005). Two meiotic crossover classes cohabit in Arabidopsis: one is dependent on MER3, whereas the other one is not. Curr. Biol. 15, 692-701.

Mercier, R., Mezard, C., Jenczewski, E., Macaisne, N., and Grelon, M. (2015). The molecular biology of meiosis in plants. Ann. Rev. Plant Biol. 66, 297-327. doi: 10.1146/annurev-arplant-050213-035923

Miao, C. B., Tang, D., Zhang, H. G., Wang, M., Li, Y. F., Tang, S. Z., et al. (2013). CENTRAL REGION COMPONENT1, a novel synaptonemal complex component, is essential for meiotic recombination initiation in rice. Plant Cell 25, 2998-3009. doi: 10.1105/tpc.113.113175

Mieulet, D., Aubert, G., Bres, C., Klein, A., Droc, G., Vieille, E., et al. (2018). Unleashing meiotic crossovers in crops. Nat. Plants 4, 1010-1016. doi: 10.1038/ s41477-018-0311-x

Miyazaki, M., Sato, Y., Asano, T., Nagamura, Y., and Nonomura, K. I. (2015). Rice MEL2, the RNA recognition motif (RRM) protein, binds in vitro to meiosisexpressed genes containing U-rich RNA consensus sequences in the 3'-UTR. Plant Mol. Biol. 89, 293-307. doi10.1007/s11103-015-0369-Z

Modliszewski, J. L., and Copenhaver, G. P. (2017). Meiotic recombination gets stressed out: CO frequency is plastic under pressure. Curr. Opin. Plant Biol. 36, 95-102. doi: 10.1016/j.pbi.2016.11.019

Modliszewski, J. L., Wang, H., Albright, A. R., Lewis, S. M., Bennett, A. R., Huang, J., et al. (2018). Elevated temperature increases meiotic crossover frequency via the interfering (Type I) pathway in Arabidopsis thaliana. PLoS Genet. 14:e1007384. doi: 10.1371/journal.pgen.1007384

Murphy, S. P., Gumber, H. K., Mao, Y., and Bass, H. W. (2014). A dynamic meiotic SUN belt includes the zygotene-stage telomere bouquet and is disrupted in chromosome segregation mutants of maize (Zea mays L.). Front. Plant Sci. 5:314. doi: $10.3389 /$ fpls.2014.00314

Nannas, N. J., Higgins, D. M., and Dawe, R. K. (2016). Anaphase asymmetry and dynamic repositioning of the division plane during maize meiosis. J. Cell Sci. $129,4014-4024$.

Nelms, B., and Walbot, V. (2019). Defining the developmental program leading to meiosis in maize. Science 364, 52-56. doi: 10.1126/science.aav6428

Nibau, C., Dadarou, D., Kargios, N., Mallioura, A., Fernandez-Fuentes, N., Cavallari, N., et al. (2020a). A functional kinase is necessary for cyclindependent kinase G1 (CDKG1) to maintain fertility at high ambient temperature in Arabidopsis. Front. Plant Sci. 11:586870. doi: 10.3389/fpls.2020. 586870

Nibau, C., Lloyd, A., Dadarou, D., Betekhtin, A., Tsilimigka, F., Phillips, D. W., et al. (2020b). CDKG1 is required for meiotic and somatic recombination intermediate processing in Arabidopsis. Plant Cell 32, 1308-1322. doi: 10.1105/ tpc. 19.00942

Nonomura, K. I., Eiguchi, M., Nakano, M., Takashima, K., Komeda, N., Fukuchi, S., et al. (2011). A novel RNA-recognition-motif protein is required for premeiotic G1/S-phase transition in rice (Oryza sativa L.). PLoS Genet. 7:e1001265. doi: 10.1371/journal.pgen.1001265

Nonomura, K. I., Morohoshi, A., Nakano, M., Eiguchi, M., Miyao, A., Hirochika, H., et al. (2007). A germ cell specific gene of the ARGONAUTE family is essential for the progression of premeiotic mitosis and meiosis during sporogenesis in rice. Plant Cell 19, 2583-2594. doi: 10.1105/tpc.107.053199

Nonomura, K. I., Nakano, M., Eiguchi, M., Suzuki, T., and Kurata, N. (2004a). PAIR2 is essential for homologous chromosome synapsis in rice meiosis I. J. Cell Sci. 119, 217-225. doi: 10.1242/jcs.02736

Nonomura, K. I., Nakano, M., Fukuda, T., Eiguchi, M., Miyao, A., Hirochika, H., et al. (2004b). The novel gene HOMOLOGOUS PAIRING ABERRATION 
IN RICE MEIOSIS1 of rice encodes a putative coiled-coil protein required for homologous chromosome pairing in meiosis. Plant Cell 16, 1008-1020. doi: $10.1105 /$ tpc.020701

Oliver, C., Pradillo, M., Jover-Gil, S., Cuñado, N., Ponce, M. R., and Santos, J. L. (2017). Loss of function of Arabidopsis microRNA-machinery genes impairs fertility, and has effects on homologous recombination and meiotic chromatin dynamics. Sci. Rep. 7:9280.

Oliver, C., Santos, J. L., and Pradillo, M. (2014). On the role of some ARGONAUTE proteins in meiosis and DNA repair in Arabidopsis thaliana. Front. Plant Sci. 5:177. doi: 10.3389/fpls.2014.00177

Oliver, C., Santos, J. L., and Pradillo, M. (2016). Accurate chromosome segregation at first meiotic division requires AGO4, a protein involved in RNA-dependent dna methylation in Arabidopsis thaliana. Genetics 204, 543-553. doi: 10.1534/ genetics.116.189217

Olivier, M., Da Ines, O., Amiard, S., Serra, H., Goubely, C., White, C. I., et al. (2015). The structure-specific endonucleases MUS81 and SEND1 are essential for telomere stability in Arabidopsis. Plant Cell. 28, 74-86. doi: 10.1105/tpc.15. 00898

Olmedo-Monfil, V., Durán-Figueroa, N., Arteaga-Vázquez, M., Demesa-Arévalo, E., Autran, D., Grimanelli, D., et al. (2010). Control of female gamete formation by a small RNA pathway in Arabidopsis. Nature 464, 628-632. doi: 10.1038/ nature 08828

Osman, K., Sanchez-Moran, E., Mann, S. C., Jones, G. H., and Franklin, F. C. H. (2009). Replication protein A (AtRPAla) is required for class I crossover formation but is dispensable for meiotic DNA break repair. EMBO J. 28, 394-404. doi: 10.1038/emboj.2008.295

Osman, K., Yang, J., Roitinger, E., Lambing, C., Heckmann, S., Howell, E., et al. (2018). Affinity proteomics reveals extensive phosphorylation of the Brassica chromosome axis protein ASY1 and a network of associated proteins at prophase I of meiosis. Plant J. 93, 17-33. doi: 10.1111/tpj.13752

Pawlowski, W. P., Golubovskaya, I. N., and Cande, W. Z. (2003). Altered nuclear distribution of recombination protein RAD51 in maize mutants suggests the involvement of RAD51 in meiotic homology recognition. Plant Cell 15, 18071816. doi: 10.1105/tpc.012898

Pawlowski, W. P., Golubovskaya, I. N., Timofejevva, L., Meeley, R. B., Sheridan, W. F., and Cande, W. Z. (2004). Coordination of meiotic recombination, pairing and synapsis by PHS1. Science 303, 89-92. doi: 10.1126/science.1091110

Pawlowski, W. P., Wang, C.-J. R., Golubovskaya, I. N., Szymaniak, J. M., Shi, L., Hamant, O., et al. (2009). Maize AMEIOTIC1 is essential for multiple early meiotic processes and likely required for the initiation of meiosis. Proc. Natl. Acad. Sci. U.S.A. 106, 3603-3608. doi: 10.1073/pnas.0810115106

Phillips, D., Jenkins, G., Macaulay, M., Nibau, C., Wnetrzak, J., Fallding, D., et al. (2015). The effect of temperature on the male and female recombination landscape of barley. New Phytol. 208, 421-429. doi: 10.1111/nph.13548

Pradillo, M., Knoll, A., Oliver, C., Varas, J., Corredor, E., Puchta, H., et al. (2015). Involvement of the Cohesin Cofactor PDS5 (SPO76) during meiosis and DNA repair in Arabidopsis thaliana. Front. Plant Sci. 6:1034. doi: 10.3389/fpls.2015. 01034

Pradillo, M., and Santos, J. L. (2018). Genes involved in miRNA biogenesis affect meiosis and fertility. Chromosome Res. 26, 233-241. doi: 10.1007/s10577-0189588- $\mathrm{x}$

Pradillo, M., Varas, J., Oliver, C., and Santos, J. L. (2014). On the role of AtDMC1, AtRAD51 and its paralogs during Arabidopsis meiosis. Front. Plant Sci. 5:23. doi: $10.3389 /$ fpls.2014.00023

Prusicki, M. A., Keizer, E. M., van Rosmalen, R. P., Komaki, S., Seifert, F., Müller, K., et al. (2019). Live cell imaging of meiosis in Arabidopsis thaliana. eLife 8:e42834.

Puizina, J., Siroky, J., Mokros, P., Schweizer, D., and Riha, K. (2004). Mre11 deficiency in Arabidopsis is associated with chromosomal instability in somatic cells and Spol1-dependent genome fragmentation during meiosis. Plant Cell 16, 1968-1978. doi: 10.1105/tpc.104.022749

Qiao, H., Lohmiller, L. D., and Anderson, L. K. (2011). Cohesin proteins load sequentially during prophase I in tomato primary microsporocytes. Chromosome Res. 19, 193-207. doi: 10.1007/s10577-010-9184-1

Ren, L., Tang, D., Zhao, T., Zhang, F., Liu, C., Xue, Z., et al. (2018). OsSPL regulates meiotic fate acquisition in rice. New Phytol. 218, 789-803. doi: 10.1111/nph. 15017
Ren, Y., Chen, D., Li, W., Zhou, D., Luo, T., Yuan, G., et al. (2019). OsSHOC1 and OsPTD1 are essential for crossover formation during rice meiosis. Plant J. 98, 315-328.

Ronceret, A., Doutriaux, M.-P., Golubovskaya, I. N., and Pawlowski, W. P. (2009). PHS1 regulates meiotic recombination and homologous chromosome pairing by controlling the transport of RAD50 to the nucleus. Proc. Natl. Acad. Sci. U.S.A. 106, 20121-20126. doi: 10.1073/pnas.0906273106

Ronceret, A., Guilleminot, J., Lincker, F., Gadea-Vacas, J., Delorme, V., Bechtold, N., et al. (2005). Genetic analysis of two Arabidopsis DNA polymerase epsilon subunits during early embryogenesis. Plant J. 44, 223-236. doi: 10.1111/j.1365313x.2005.02521.x

Ronceret, A., and Pawlowski, W. P. (2010). Chromosome dynamics in meiotic prophase I in plants. Cytogenet. Genome Res. 129, 173-183. doi: 10.1159/ 000313656

Rowan, B. A., Heavens, D., Feuerborn, T. R., Tock, A. J., Henderson, I. R., and Weigel, D. (2019). An ultra high-density Arabidopsis thaliana crossover map that refines the influences of structural variation and epigenetic features. Genetics 213, 771-787. doi: 10.1534/genetics.119.302406

Saini, R., Singh, A. K., Dhanapal, S., Saeed, T. H., Hyde, G. J., and Baskar, R. (2017). Brief temperature stress during reproductive stages alters meiotic recombination and somatic mutation rates in the progeny of Arabidopsis. BMC Plant Biol. 17:103. doi: 10.1186/s12870-017-1051-1

Saini, R., Singh, A. K., Hyde, G. J., and Baskar, R. (2020). Levels of heterochiasmy during Arabidopsis development as reported by fluorescent tagged lines. G3 10, 2103-2110. doi: 10.1534/g3.120.401296

Šamanić, I., Simunić, J., Riha, K., and Puizina, J. (2013). Evidence for distinct functions of MRE11 in Arabidopsis meiosis. PLoS One 8:e78760. doi: 10.1371/ journal.pone.0078760

Seeliger, K., Dukowic-Schulze, S., Wurz-Wildersinn, R., Pacher, M., and Puchta, H. (2012). BRCA2 is a mediator of RAD51- and DMC1-facilitated homologous recombination in Arabidopsis thaliana. New Phytol. 193, 364-375. doi: 10.1111/ j.1469-8137.2011.03947.x

Séguéla-Arnaud, M., Crismani, W., Larchevêque, C., Mazel, J., Froger, N., Choinard, S., et al. (2015). Multiple mechanisms limit meiotic crossovers: TOP $3 \alpha$ and two BLM homologs antagonize crossovers in parallel to FANCM. Proc. Natl. Acad. Sci. U.S.A. 112, 4713-4718. doi: 10.1073/pnas.1423107112

Sepsi, A., and Schwarzacher, T. (2020). Chromosome-nuclear envelope tethering a process that orchestrates homologue pairing during plant meiosis? J. Cell Sci. 133:jcs243667.

Serra, H., Lambing, C., Griffin, C. H., Topp, S. D., Nageswaran, D. C., Underwood, C. J., et al. (2018). Massive crossover elevation via combination of HEI10 and recq4a recq4b during Arabidopsis meiosis. Proc. Natl. Acad. Sci. U.S.A. 115, 2437-2442. doi: 10.1073/pnas.1713071115

Shi, W., Ji, J., Xue, Z., Zhang, F., Miao, Y., Yang, H., et al. (2021). PRD1, a homologous recombination initiation factor, is involved in spindle assembly in rice meiosis. New Phytol. 230, 585-600. doi: 10.1111/nph.17178

Shi, W., Tang, D., Shen, Y., Xue, Z., Zhang, F., Zhang, C., et al. (2019). OsHOP2 regulates the maturation of crossovers by promoting homologous pairing and synapsis in rice meiosis. New Phytol. 222, 805-819. doi: 10.1111/nph.15664

Shilo, S., Melamed-Bessudo, C., Dorone, Y., Barkai, N., and Levy, A. A. (2015). DNA crossover motifs associated with epigenetic modifications delineate open chromatin regions in Arabidopsis. Plant Cell 27, 2427-2436. doi: 10.1105/tpc. 15.00391

Siaud, N., Dray, E., Gy, I., Gerard, E., Takvorian, N., and Doutriaux, M. P. (2004). Brca2 is involved in meiosis in Arabidopsis thaliana as suggested by its interaction with Dmc1. EMBO J. 23, 1392-1401. doi: 10.1038/sj.emboj.7600146

Sidhu, G. K., Fang, C., Olson, M. A., Falque, M., Martin, O. C., and Pawlowski, W. P. (2015). Recombination patterns in maize reveal limits to crossover homeostasis. Proc. Natl. Acad. Sci. U.S.A. 112, 15982-15987. doi: 10.1073/pnas. 1514265112

Sims, J., Copenhaver, G. P., and Schlögelhofer, P. (2019). Meiotic DNA repair in the nucleolus employs a nonhomologous end-joining mechanism. Plant Cell 31, 2259-2275. doi: 10.1105/tpc.19.00367

Singh, D. K., Andreuzza, S., Panoli, A. P., and Siddiqi, I. (2013). AtCTF7 is required for establishment of sister chromatid cohesion and association of cohesin with chromatin during meiosis in Arabidopsis. BMC Plant Biol. 13:117. doi: 10.1186/ 1471-2229-13-117 
Singh, G., Da Ines, O., Gallego, M. E., and White, C. I. (2017). Analysis of the impact of the absence of RAD51 strand exchange activity in Arabidopsis meiosis. PLoS One 12:e0183006. doi: 10.1371/journal.pone.0183006

Stacey, N. J., Kuromori, T., Azumi, Y., Roberts, G., Breuer, C., Wada, T., et al. (2006). Arabidopsis SPO11-2 functions with SPO11-1 in meiotic recombination. Plant J. 48, 206-216. doi: 10.1111/j.1365-313x.2006.02867.x

Stack, S. M., Shearer, L. A., Lohmiller, L., and Anderson, L. K. (2017). Meiotic crossing over in maize knob heterochromatin. Genetics 205, 1101-1112. doi: 10.1534/genetics.116.196089

Su, H., Cheng, Z., Huang, J., Lin, J., Copenhaver, G. P., Ma, H., et al. (2017). Arabidopsis RAD51, RAD51C and XRCC3 proteins form a complex and facilitate RAD51 localization on chromosomes for meiotic recombination. PLoS Genet. 13:e1006827. doi: 10.1371/journal.pgen.100 6827

Svačina, R., Sourdille, P., Kopecký, D., and Bartoš, J. (2020). Chromosome pairing in polyploid grasses. Front. Plant Sci. 11:1056. doi: 10.3389/fpls.2020.01056

Taagen, E., Bogdanove, A. J., and Sorrells, M. E. (2020). Counting on crossovers: controlled recombination for plant breeding. Trends Plant Sci. 25, 455-465. doi: 10.1016/j.tplants.2019.12.017

Tang, Y., Yin, Z., Zeng, Y., Zhang, Q., Chen, L., He, Y., et al. (2017). MTOPVIB interacts with AtPRD1 and plays important roles in formation of meiotic DNA double-strand breaks in Arabidopsis. Sci Rep. 7:10007.

Termolino, P., Falque, M., Aiese Cigliano, R., Cremona, G., Paparo, R., Ederveen, A., et al. (2019). Recombination suppression in heterozygotes for a pericentric inversion induces the interchromosomal effect on crossovers in Arabidopsis. Plant J. 100, 1163-1175. doi: 10.1111/tpj.14505

Tock, A. J., and Henderson, I. R. (2018). Hotspots for initiation of meiotic recombination. Front. Genet. 9:521. doi: 10.3389/fgene.2018.00521

Toyota, M., Matsuda, K., Kakutani, T., Terao Morita, M., and Tasaka, M. (2011). Developmental changes in crossover frequency in Arabidopsis. Plant J. 65, 589-599. doi: 10.1111/j.1365-313x.2010.04440.x

Uanschou, C., Ronceret, A., Von Harder, M., De Muyt, A., Vezon, D., Pereira, L., et al. (2013). Sufficient amounts of functional HOP2/MND1 complex promote interhomolog DNA repair but are dispensable for intersister dna repair during meiosis in Arabidopsis. Plant Cell 25, 4924-4940. doi: 10.1105/tpc.113.118521

Uanschou, C., Siwiec, T., Pedrosa-Harand, A., Kerzendorfer, C., Sanchez-Moran, E., Novatchkova, M., et al. (2007). A novel plant gene essential for meiosis is related to the human CtIP and the yeast COM1/SAE2 gene. EMBO J. 26, 5061-5070. doi: 10.1038/sj.emboj.7601913

Underwood, C. J., Choi, K., Lambing, C., Zhao, X., Serra, H., Borges, F., et al. (2018). Epigenetic activation of meiotic recombination near Arabidopsis thaliana centromeres via loss of $\mathrm{H} 3 \mathrm{~K} 9 \mathrm{me} 2$ and non-CG DNA methylation. Genome Res. 28, 519-531. doi: 10.1101/gr.227116.117

Varas, J., Graumann, K., Osman, K., Pradillo, M., Evans, D. E., Santos, J. L., et al. (2015). Absence of SUN1 and SUN2 proteins in Arabidopsis thaliana leads to a delay in meiotic progression and defects in synapsis and recombination. Plant J. 81, 329-346. doi: 10.1111/tpj.12730

Vignard, J., Siwiec, T., Chelysheva, L., Vrielynck, N., Gonord, F., Armstrong, S. J., et al. (2007). The interplay of RecA-related proteins and the MND1-HOP2 complex during meiosis in Arabidopsis thaliana. PLoS Genet. 3:1894-1906. doi: 10.1371/journal.pgen.0030176

von Wettstein, D., Rasmussen, S. W., and Holm, P. B. (1984). The synaptonemal complex in genetic segregation. Annu. Rev. Genet. 18, 331-413. doi: 10.1146/ annurev.ge.18.120184.001555

Vrielynck, N., Chambon, A., Vezon, D., Pereira, L., Chelysheva, L., De Muyt, A., et al. (2016). A DNA topoisomerase VI-like complex initiates meiotic recombination. Science 351, 939-943. doi: 10.1126/science.aad 5196

Walker, J., Gao, H., Zhang, J., Aldridge, B., Vickers, M., Higgins, J. D., et al. (2018). Sexual-lineage-specific DNA methylation regulates meiosis in Arabidopsis. Nat. Genet. 50, 130-137. doi: 10.1038/s41588-017-0008-5

Wang, C., Higgins, J. D., He, Y., Lu, P., Zhang, D., and Liang, W. (2017). Resolvase OsGEN1 mediates DNA repair by homologous recombination. Plant Physiol. 173, 1316-1329. doi: 10.1104/pp.16.01726

Wang, C., Huang, J., Zhang, J., Wang, H., Han, Y., Copenhaver, G. P., et al. (2018). The largest subunit of DNA polymerase delta is required for normal formation of meiotic type I crossovers. Plant Physiol. 179, 446-459. doi: 10.1104/pp.18. 00861
Wang, C.-J. R., Carlton, P. M., Golubovskaya, I. N., and Cande, W. Z. (2009). Interlock formation and coiling of meiotic chromosome axes during synapsis. Genetics 183, 905-915. doi: 10.1534/genetics.109.108688

Wang, H., Hu, Q., Tang, D., Liu, X., Du, G., Shen, Y., et al. (2016). OsDMC1 is not required for homologous pairing in rice meiosis. Plant Physiol. 171, 230-241. doi: $10.1104 / \mathrm{pp} .16 .00167$

Wang, H., Xu, W., Sun, Y., Lian, Q., Wang, C., Yu, C., et al. (2020). The cohesin loader SCC2 contains a PHD finger that is required for meiosis in land plants. PLoS Genet. 16:e1008849. doi: 10.1371/journal.pgen.1008849

Wang, K., Wang, M., Tang, D., Shen, Y., Qin, B., Li, M., et al. (2011). PAIR3, an axis-associated protein, is essential for the recruitment of recombination elements onto meiotic chromosomes in rice. Mol. Biol. Cell. 22, 12-19. doi: 10.1091/mbc.e10-08-0667

Wang, M., Wang, K., Tang, D., Wei, C., Li, M., Shen, Y., et al. (2010). The central element protein ZEP1 of the synaptonemal complex regulates the number of crossovers during meiosis in rice. Plant Cell 22, 417-430. doi: 10.1105/tpc.109. 070789

Wang, S., Veller, C., Sun, F., Ruiz-Herrera, A., Shang, Y., Liu, H., et al. (2019). Pernucleus crossover covariation and implications for evolution. Cell 177, 326-338. doi: 10.1016/j.cell.2019.02.021

Wang, Y., and Copenhaver, G. P. (2018). Meiotic recombination: mixing it up in plants. Ann. Rev. Plant Biol. 69, 577-609. doi: 10.1146/annurev-arplant042817-040431

Wang, Y., Jiang, L., Zhang, T., Jing, J., and He, Y. (2018). ZmCom1 is required for both mitotic and meiotic recombination in maize. Front. Plant Sci. 9:1005. doi: 10.3389/fpls.2018.01005

Waterworth, W. M., Altun, C., Armstrong, S. J., Roberts, N., Dean, P. J., Young, K., et al. (2007). NBS1 is involved in DNA repair and plays a synergistic role with ATM in mediating meiotic homologous recombination in plants. Plant $\mathrm{J}$. 52, 41-52. doi: 10.1111/j.1365-313X.2007.03220.x

Wei, B., Zhang, J., Pang, C., Yu, H., Guo, D., Jiang, H., et al. (2015). The molecular mechanism of SPOROCYTELESS/NOZZLE in controlling Arabidopsis ovule development. Cell Res. 25, 121-134. doi: 10.1038/cr.2014.145

West, A. M. V., Rosenberg, S. C., Ur, S. N., Lehmer, M. K., Ye, Q., Hagemann, G., et al. (2019). A conserved filamentous assembly underlies the structure of the meiotic chromosome axis. eLife 8:e40372.

Wijnker, E., Harashima, H., Müller, K., Parra-Nuñez, P., de Snoo, C. B., van de Belt, J., et al. (2019). The Cdk1/Cdk2 homolog CDKA;1 controls the recombination landscape in Arabidopsis. Proc. Natl. Acad Sci. U.S.A. 116, 12534-12539. doi: 10.1073/pnas.1820753116

Wilkins, A. S., and Holliday, R. (2009). The evolution of meiosis from mitosis. Genetics 181, 3-12. doi: 10.1534/genetics.108.099762

Xue, M., Wang, J., Jiang, L., Wang, M., Wolfe, S., Pawlowski, W. P., et al. (2018). The number of meiotic double-strand breaks influences crossover distribution in Arabidopsis. Plant Cell 30, 2628-2638. doi: 10.1105/tpc.18.00531

Xue, Z., Li, Y., Zhang, L., Shi, W., Zhang, C., Feng, M., et al. (2016). OsMTOPVIB promotes meiotic DNA double-strand break formation in rice. Mol. Plant 9, 1535-1538. doi: 10.1016/j.molp.2016.07.005

Xue, Z., Liu, C., Shi, W., Miao, Y., Shen, Y., Tang, D., et al. (2019). OsMTOPVIB is required for meiotic bipolar spindle assembly. Proc. Natl. Acad. Sci. U.S.A. 116, 15967-15972. doi: 10.1073/pnas.1821315116

Yang, C., Hamamura, Y., Sofroni, K., Böwer, F., Stolze, S. C., Nakagami, H., et al. (2019). SWITCH 1/DYAD is a WINGS APART-LIKE antagonist that maintains sister chromatid cohesion in meiosis. Nat. Commun. 10:1755.

Yang, C., Sofroni, K., Wijnker, E., Hamamura, Y., Carstens, L., Harashima, H., et al. (2020). The Arabidopsis Cdk1/Cdk2 homolog CDKA;1 controls chromosome axis assembly during plant meiosis. EMBO J. 39:e101625.

Yang, W. C., Ye, D., Xu, J., and Sundaresan, V. (1999). The SPOROCYTELESS gene of Arabidopsis is required for initiation of sporogenesis and encodes a novel nuclear protein. Genes Dev. 13, 2108-2117. doi: 10.1101/gad.13.16.2108

Yin, H., Zhang, X., Liu, J., Wang, Y., He, J., Yang, T., et al. (2009). Epigenetic regulation, somatic homologous recombination, and abscisic acid signaling are influenced by DNA polymerase \{epsilon\} mutation in Arabidopsis. Plant Cell 21, 386-402. doi: 10.1105/tpc.108.061549

Yuan, G., Ahootapeh, B. H., Komaki, S., Schnittger, A., Lillo, C., De Storme, N., et al. (2018). PROTEIN PHOSHATASE 2A B' $\alpha$ and $\beta$ maintain centromeric sister chromatid cohesion during meiosis in Arabidopsis. Plant Physiol. 178, 317-328. doi: 10.1104/pp.18.00281 
Yuan, W. Y., Li, X. W., Chang, Y. X., Wen, R. Y., Chen, G. X., Zhang, Q. F., et al. (2009). Mutation of the rice gene PAIR3 results in lack of bivalent formation in meiosis. Plant J. 59, 303-315. doi: 10.1111/j.1365-313X.2009.03870.x

Zamariola, L., De Storme, N., Vannerum, K., Vandepoele, K., Armstrong, S. J., Franklin, F. C. H., et al. (2014). SHUGOSHINs and PATRONUS protect meiotic centromere cohesion in Arabidopsis thaliana. Plant J. 77, 782-794. doi: 10.1111/ tpj.12432

Zelkowski, M., Olson, M. A., Wang, M., and Pawlowski, W. (2019). Diversity and determinants of meiotic recombination landscapes. Trends Genet. 35, 359-370. doi: 10.1016/j.tig.2019.02.002

Zhang, C., Song, Y., Cheng, Z. H., Wang, Y. X., Zhu, J., Ma, H., et al. (2012). The Arabidopsis thaliana DSB formation (AtDFO) gene is required for meiotic double-strand break formation. Plant J. 72, 271-281. doi: 10.1111/j.1365-313x. 2012.05075.x

Zhang, C., Zhang, F., Cheng, X., Liu, K., Tang, J., Li, Y., et al. (2020a). OsATM safeguards accurate repair of meiotic double-strand breaks in rice. Plant Physiol. 183, 1047-1057. doi: 10.1104/pp.20.00053

Zhang, F., Ma, L., Zhang, C., Du, G., Shen, Y., Tang, D., et al. (2020b). The SUN domain proteins OsSUN1 and OsSUN2 play critical but partially redundant roles in meiosis. Plant Physiol. 183, 1517-1530. doi: 10.1104/pp.20.00140

Zhang, F., Shen, Y., Miao, C., Cao, Y., Shi, W., Du, G., et al. (2020c). OsRAD51D promotes homologous pairing and recombination by preventing nonhomologous interactions in rice meiosis. New Phytol. 227, 824-839. doi: 10.1111/nph.16595

Zhang, F., Tang, D., Shen, Y., Xue, Z., Shi, W., Ren, L., et al. (2017). The F-box protein ZYGO1 mediates bouquet formation to promote homologous pairing, synapsis, and recombination in rice meiosis. Plant Cell 29, 2597-2609. doi: $10.1105 /$ tpc.17.00287

Zhang, J., Feng, C., Su, H., Liu, Y., Liu, Y., and Han, F. (2020d). The cohesin complex subunit ZmSMC3 participates in meiotic centromere pairing in maize. Plant Cell 32, 1323-1336. doi: 10.1105/tpc.19.00834

Zhang, M., Ma, X., Wang, C., Li, Q., Meyers, B. C., Springer, N. M., et al. (2021). CHH DNA methylation increases at 24-PHAS loci depend on 24-nt phased small interfering RNAs in maize meiotic anthers. New Phytol. 229, 2984-2997. doi: $10.1111 /$ nph.17060

Zhang, P., Zhang, Y., Sun, L., Sinumporn, S., Yang, Z., Sun, B., et al. (2017). The Rice AAA-ATPase OsFIGNL1 Is essential for male meiosis. Front Plant Sci. 8:1639. doi: 10.3389/fpls.2017.01639

Zhang, Y.-L., Zhang, H., Gao, Y.-J., Yan, L.-L., Yu, X.-Y., Yang, Y.-H., et al. (2019). Protein Phosphatase $2 \mathrm{~A} \mathrm{~B} \alpha$ and $\mathrm{B}^{\prime} \beta$ protect centromeric cohesion during meiosis I. Plant Physiol. 179, 1556-1568. doi: 10.1104/pp.18.01320
Zhao, M., Ku, J.-C., Liu, B., Yang, D., Yin, L., Ferrell, T. J., et al. (2021). The mopl mutation affects the recombination landscape in maize. Proc. Natl. Acad. Sci. U.S.A. 118:e2009475118. doi: 10.1073/pnas.20094 75118

Zhao, X. A., Bramsiepe, J., Van Durme, M., Komaki, S., Prusicki, M. A., Maruyama, D., et al. (2017). RETINOBLASTOMA RELATED1 mediates germline entry in Arabidopsis. Science 356:eaaf6532. doi: 10.1126/science.aaf 6532

Zheng, T., Nibau, C., Phillips, D. W., Jenkins, G., Armstrong, S. J., and Doonan, J. H. (2014). CDKG1 protein kinase is essential for synapsis and male meiosis at high ambient temperature in Arabidopsis thaliana. Proc. Natl. Acad Sci. U.S.A. 111, 2182-2187. doi: 10.1073/pnas.1318460111

Zickler, D., and Kleckner, N. (2015). Recombination, pairing, and synapsis of homologs during meiosis. Cold Spring Harb. Perspect. Biol. 7:a016626. doi: 10.1101/cshperspect.a016626

Ziolkowski, P. A., Berchowitz, L. E., Lambing, C., Yelina, N. E., Zhao, X., Kelly, K. A., et al. (2015). Juxtaposition of heterozygous and homozygous regions causes reciprocal crossover remodelling via interference during Arabidopsis meiosis. Elife 4:e03708.

Ziolkowski, P. A., Underwood, C. J., Lambing, C., Martinez-Garcia, M., Lawrence, E. J., Ziolkowska, L., et al. (2017). Natural variation and dosage of the HEI10 meiotic E3 ligase control Arabidopsis crossover recombination. Genes Dev. 31, 306-317. doi: 10.1101/gad.295501.116

Conflict of Interest: The authors declare that the research was conducted in the absence of any commercial or financial relationships that could be construed as a potential conflict of interest.

Publisher's Note: All claims expressed in this article are solely those of the authors and do not necessarily represent those of their affiliated organizations, or those of the publisher, the editors and the reviewers. Any product that may be evaluated in this article, or claim that may be made by its manufacturer, is not guaranteed or endorsed by the publisher.

Copyright (c) 2021 Gutiérrez Pinzón, González Kise, Rueda and Ronceret. This is an open-access article distributed under the terms of the Creative Commons Attribution License (CC BY). The use, distribution or reproduction in other forums is permitted, provided the original author(s) and the copyright owner(s) are credited and that the original publication in this journal is cited, in accordance with accepted academic practice. No use, distribution or reproduction is permitted which does not comply with these terms. 